Article

\title{
Effect of Low Temperature on Chlorophyll Biosynthesis and Chloroplast Biogenesis of Rice Seedlings during Greening
}

\author{
Yuqing Zhao ${ }^{1,+}{ }^{\dagger}$ Qiaohong Han ${ }^{1,+}$, Chunbang Ding ${ }^{1}$, Yan Huang ${ }^{1}$, Jinqiu Liao ${ }^{1}$, Tao Chen ${ }^{1}$, \\ Shiling Feng ${ }^{1}$, Lijun Zhou ${ }^{1} \mathbb{1}$, Zhongwei Zhang ${ }^{2}$, Yanger Chen ${ }^{1}{ }^{1}$, Shu Yuan ${ }^{2}{ }^{\mathbb{D}}$ and \\ Ming Yuan ${ }^{1, *}$ \\ 1 College of Life Science, Sichuan Agricultural University, Ya'an 625014, China; \\ yuqing@stu.sicau.edu.cn (Y.Z.); xiaoyangyang26@126.com (Q.H.); dcb@sicau.edu.cn (C.D.); \\ shirley11hy@163.com (Y.H.); liaojinqiu630@sicau.edu.cn (J.L.); chentao293@163.com (T.C.); \\ fengshilin@outlook.com (S.F.); zhoulijun@sicau.edu.cn (L.Z.); anty9826@163.com (Y.C.) \\ 2 College of Resources, Sichuan Agricultural University, Chengdu 611130, China; \\ zzwzhang@sicau.edu.cn (Z.Z.); roundtree@sohu.com (S.Y.) \\ * Correspondence: yuanming@sicau.edu.cn \\ + These authors contribute equally to this work.
}

Received: 14 December 2019; Accepted: 17 February 2020; Published: 19 February 2020

\begin{abstract}
Rice (Oryza sativa L.) frequently suffers in late spring from severe damage due to cold spells, which causes the block of chlorophyll biosynthesis during early rice seedling greening. However, the inhibitory mechanism by which this occurs is still unclear. To explore the responsive mechanism of rice seedlings to low temperatures during greening, the effects of chilling stress on chlorophyll biosynthesis and plastid development were studied in rice seedlings. Chlorophyll biosynthesis was obviously inhibited and chlorophyll accumulation declined under low temperatures during greening. The decrease in chlorophyll synthesis was due to the inhibited synthesis of $\delta$-aminolevulinic acid (ALA) and the suppression of conversion from protochlorophyllide (Pchlide) into chlorophylls (Chls). Meanwhile, the activities of glutamate-1-semialdehyde transaminase (GSA-AT), Mg-chelatase, and protochlorophyllide oxidoreductase (POR) were downregulated under low temperatures. Further investigations showed that chloroplasts at $18{ }^{\circ} \mathrm{C}$ had loose granum lamellae, while the thylakoid and lamellar structures of grana could hardly develop at $12{ }^{\circ} \mathrm{C}$ after $48 \mathrm{~h}$ of greening. Additionally, photosystem II (PSII) and photosystem I (PSI) proteins obviously declined in the stressed seedlings, to the point that the PSII and PSI proteins could hardly be detected after $48 \mathrm{~h}$ of greening at $12{ }^{\circ} \mathrm{C}$. Furthermore, the accumulation of reactive oxygen species (ROS) and malondialdehyde (MDA) and cell death were all induced by low temperature. Chilling stress had no effect on the development of epidermis cells, but the stomata were smaller under chilling stress than those at $28^{\circ} \mathrm{C}$. Taken together, our study promotes more comprehensive understanding in that chilling could inhibit chlorophyll biosynthesis and cause oxidative damages during greening.
\end{abstract}

Keywords: Oryza sativa L.; chilling stress; chlorophyll biosynthesis; chloroplast biogenesis; epidermal characteristics

\section{Introduction}

Seedlings, growing in the darkness before emerging from the soil, undergo etiolation with long hypocotyls and closed cotyledons which contain undeveloped plastids called etioplasts that have no chlorophyll [1,2]. The greening process initiates when exposed to light as the seedlings come out of soil, and this de-etiolation process includes the reduction of hypocotyl elongation rate, cotyledon opening, 
chlorophyll synthesis, and chloroplast biogenesis, and subsequently, seedlings absorb light energy and transition to autotrophy [3,4].

Chlorophyll (Chl) has unique and essential roles in harvesting and transducing light energy in antenna systems, and charge separation and electron transport in reaction centers [5,6]. Chlorophyll level is an important index used to evaluate photosynthetic capacity. Chlorophyll content decreases under cold stress, which might be because low temperature suppresses chlorophyll biosynthesis, probably by inhibiting the activities of chlorophyll biosynthetic enzymes [7]. A previous study showed that the optimum temperature of divinyl reductase (DVR) activity was $30^{\circ} \mathrm{C}$, and low activity was observed at $10{ }^{\circ} \mathrm{C}$ and no activity was found at $50{ }^{\circ} \mathrm{C}$ [7].

Chls share a common biosynthetic pathway with other tetrapyrroles, including siroheme, heme, and phytochromobilin in plants, algae, and many bacteria $[6,8,9]$. Since tetrapyrrole intermediates are all photosensitizers that are easily activated by light, leading to highly toxic levels of reactive oxygen species (ROS) and photooxidative damage and growth retardation, $\mathrm{Chl}$ biosynthesis must be finely controlled to ensure healthy growth during the greening process $[9,10]$. Chl biosynthesis is a very complex process that is executed via a series of coordinated reactions catalyzed by numerous enzymes [11]. The process of $\mathrm{Chl}$ biosynthesis can be divided into three distinct phases. The first phase involves the synthesis of protoporphyrin IX (Proto IX) from glutamate [12]. The first committed precursor is $\delta$-aminolevulinic acid (ALA), and its synthesis is a key control point in Chl biosynthesis. This step is catalyzed by glutamyl-tRNA reductase (GluTR), which is encoded by HEMA gene [8]. $\delta$-Aminolevulinic acid dehydratase (ALAD) catalyzes aggregation of two ALA molecules into porphobilinogen (PBG). Four PBGs polymerize and further cyclize to yield uroporphyrinogen III (urogen III), when then decarboxylates to form coproporphyrinogen III (coprogen III). Coprogen III occurs via oxidative decarboxylation and oxygen-dependent aromatization reaction to form protoporphyrin IX (Proto IX) [9]. The second phase includes the synthesis of chlorophyll $a$ (Chla) from Proto IX. Proto IX is the branch point of the chlorophyll and heme biosynthetic pathways [6]. The insertion of $\mathrm{Mg}^{2+}$ into Proto IX forms Mg-protoporphyrin IX (Mg-proto IX), which is catalyzed by Mg-chelatase, but the insertion of $\mathrm{Fe}^{2+}$ into Proto IX catalyzed by ferrochelatase starts the heme branch [9]. Meanwhile, the photoreduction of Pchlide to chlorophyllide (Chlide), catalyzed by protochlorophyllide oxidoreductase (POR), is another important step. POR is the key enzyme in the light-dependent greening of higher plants [13]. Two POR proteins (PORA and PORB) and three POR proteins (PORA, PORB, and PORC) have been found in rice and Arabidopsis, respectively [14,15]. DVR catalyzes 3,8-divinyl-chlide $a$ to yield chlorophyllide a (Chlide a), which further forms $\mathrm{Chl} a$ catalyzed by chlorophyll synthase (CHLG). The third phase is the interconversion of $\mathrm{Chl} a$ and chlorophyll $b(\mathrm{Chl} b)$ catalyzed by chlorophyllide a oxygenase (CAO) which is known as the chlorophyll cycle [16].

Chloroplasts are responsible for photosynthesis and the production of hormones and metabolites [17,18], which develop from proplastids that are present in the immature cells of plant meristems. Chloroplast biogenesis involves a coordinated function of plastid- and nuclear-encoded genes [19]. The process of chloroplast biogenesis accompanies the biosynthesis of chlorophylls, chloroplast proteins, carotenoids, and lipids, and the assembly of photosynthetic protein complexes including the light-harvesting complex (LHC), photosystem I (PSI), photosystem II (PSII), cytochrome $f / b_{6}\left(\mathrm{cyt} f / b_{6}\right)$, and adenosine triphosphate (ATP) synthase [1,17]. Many factors have direct impacts on chloroplast biogenesis, such as light, water, salt, leaf age, etc. [1,20].

Low temperature is one of the most severe weather events that destructively affect crop growth, quality, and yield [21,22]. Cold or chilling stress impairs the chloroplast microstructure, photosynthetic metabolism, and energy production [23], directly leading to inhibited photosynthesis, which is a severe threat to crop production. Additionally, the efficiency of photosynthetic electron transport in plants is significantly decreased under chilling stress, resulting in a burst of ROS that directly causes cellular oxidative damages and increases membrane rigidity [24-27]. Low temperature also disrupts the carbon reduction cycle and the control of stomatal conductance [28]. 
Rice (Oryza sativa L.) is a kind of thermophilic cereal crop that feeds almost half of the world's population. Originating from tropical and subtropical areas, rice is highly sensitive to low temperatures, particularly during the greening process of the early seedling growth. In China, cold spells in late spring cause serious suppression of rice seed germination and young seedling growth, especially in the middle-lower Yangtze River region and southern China. In the past 30 years, 30\%-50\% rice seedlings suffered from chilling or cold stress, resulting in a reduction of 3-5 megatons every year [29].

Chlorophyll biosynthesis is seriously blocked by low temperatures during greening. However, the inhibitory mechanism by which this occurs is still unclear. Understanding how rice responds to low temperatures will provide valuable information and genetic resources for improving cold-stress tolerance. Therefore, the object of this study was to explore the response mechanism of chlorophyll biosynthesis and chloroplast biogenesis during the greening process under chilling stress and to provide valuable data for crop production.

\section{Results}

\subsection{Effect of Chilling Stress on Plant Growth}

To investigate the effect of chilling stress on the growth of rice seedlings during greening, 6 day etiolated seedlings were treated with $28{ }^{\circ} \mathrm{C}, 18{ }^{\circ} \mathrm{C}$, and $12{ }^{\circ} \mathrm{C}$ for $48 \mathrm{~h}$ in light $\left(120 \mu \mathrm{mol} \mathrm{m} \mathrm{m}^{-2} \mathrm{~s}^{-1}\right)$. After $48 \mathrm{~h}$ of greening, leaves were green and fully expanded at $28^{\circ} \mathrm{C}$ (Figure $1 \mathrm{~A}, \mathrm{~B}$ ) and the leaves at $18{ }^{\circ} \mathrm{C}$ looked yellow-green and were fully expanded, while the leaves at $12{ }^{\circ} \mathrm{C}$ were yellow and incompletely expanded (Figure 1A,B). Compared with plants growing at $28^{\circ} \mathrm{C}$, chill-treated rice seedlings exhibited significantly lower shoot and root lengths after $48 \mathrm{~h}$ illumination (Figure 1C). These results showed that chilling stress significantly inhibited the greening process and the growth of rice seedlings.
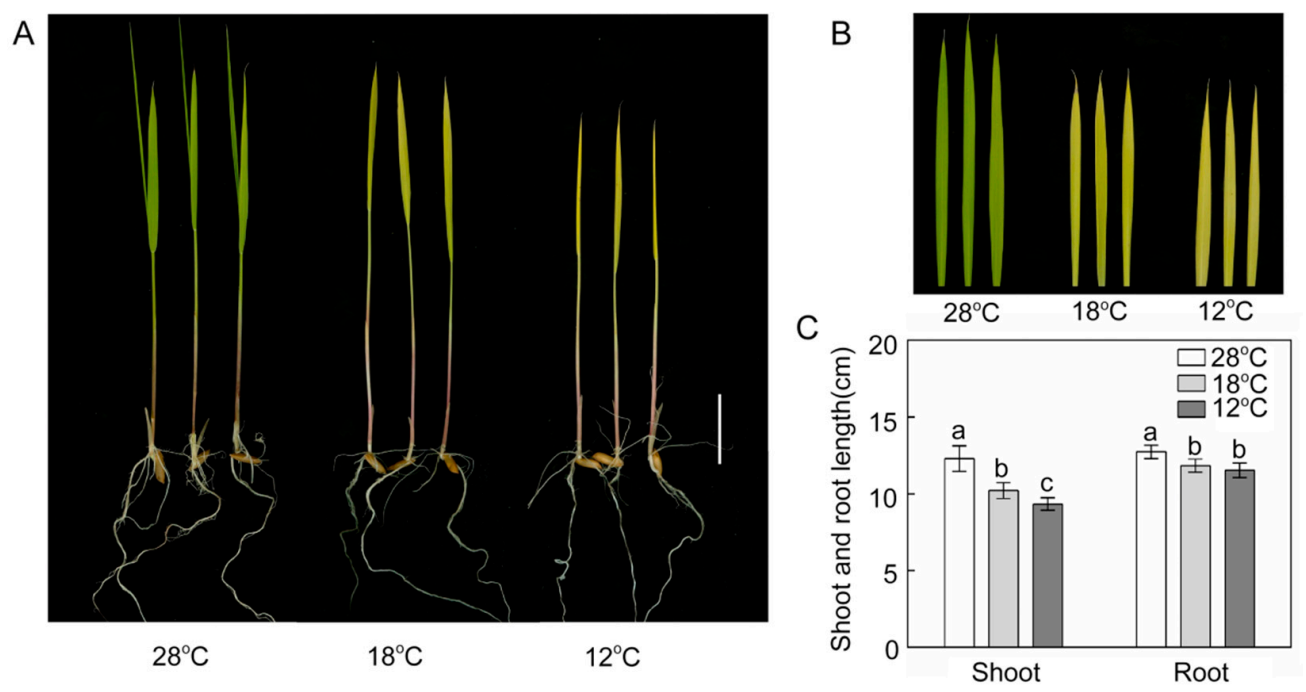

Figure 1. Effect of chilling stress on rice seedling growth $(\mathbf{A}, \mathbf{B})$ and shoot/root length (C) after $48 \mathrm{~h}$ of greening. Six day old etiolated seedlings were treated with $18{ }^{\circ} \mathrm{C}$ or $12{ }^{\circ} \mathrm{C}$ chilling stress. Date represent means \pm SD of 10 replicate samples. Bars with different letters above the columns of figures indicate significant differences according to Duncan's multiple range test at $p<0$. Bar $=2 \mathrm{~cm}$.

\subsection{Effect of Chilling Stress on Dry Weight, Protein, Chlorophyll, and Carotenoid Content}

The dry weight (DW) of shoots was increased by $1.8 \%, 17.3 \%$, and $56.5 \%$, respectively, at $28{ }^{\circ} \mathrm{C}$ after $0.5 \mathrm{~h}, 12 \mathrm{~h}$, and $48 \mathrm{~h}$ of light exposure (Figure 2A). However, the accumulation of dry matter was significantly inhibited under chilling stress. Shoot DWs were $10.3 \%$ and $20.7 \%$ lower after $12 \mathrm{~h}$ and $48 \mathrm{~h}$ at $18{ }^{\circ} \mathrm{C}$ compared with those at $28^{\circ} \mathrm{C}$. More severely, DWs at $12{ }^{\circ} \mathrm{C}$ were $13.2 \%$ and $34.1 \%$ lower 
after $12 \mathrm{~h}$ and $48 \mathrm{~h}$ of light exposure compared with those at $28^{\circ} \mathrm{C}$, and showed no significant change compared with the seedlings before the light exposure.

At $28^{\circ} \mathrm{C}$, protein contents of seedlings rose to $16.38,22.74$, and $37.90 \mathrm{mg} \cdot \mathrm{g}^{-1}$ fresh weight $(\mathrm{FW})$ after $0.5 \mathrm{~h}, 12 \mathrm{~h}$, and $48 \mathrm{~h}$ of greening, respectively (Figure 2B). Low temperature reduced protein accumulation of rice seedlings during the greening process. There were only $22.41 \mathrm{mg} \cdot \mathrm{g}^{-1} \mathrm{FW}$ at $18^{\circ} \mathrm{C}$ and $17.31 \mathrm{mg} \cdot \mathrm{g}^{-1} \mathrm{FW}$ at $12{ }^{\circ} \mathrm{C}$ after $48 \mathrm{~h}$ of light exposure.

Chlorophyll during the greening process was significantly increased at $28^{\circ} \mathrm{C}$. However, chlorophyll levels were $77.1 \%$ lower at $18{ }^{\circ} \mathrm{C}$ and $97.5 \%$ lower at $12{ }^{\circ} \mathrm{C}$ than at $28{ }^{\circ} \mathrm{C}$ (Figure 2C). Carotenoids at $28^{\circ} \mathrm{C}$ increased to $0.21 \mathrm{mg} \cdot \mathrm{g}^{-1} \mathrm{FW}$ after $48 \mathrm{~h}$ of greening, while chill-stressed rice seedlings accumulated much lower levels of carotenoids (Figure 2D).
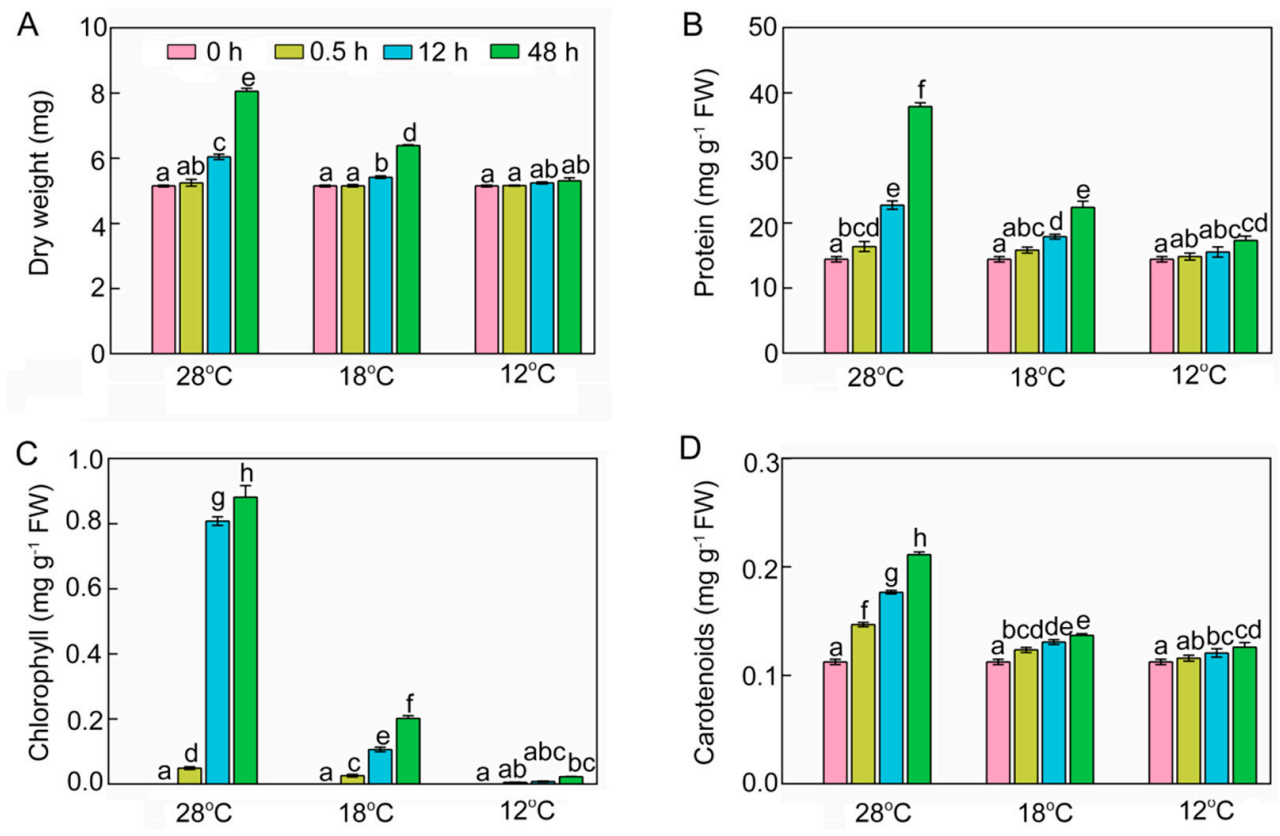

Figure 2. Dry weight (DW, A), soluble protein (B), chlorophyll (C), and carotenoids (D) of control $\left(28{ }^{\circ} \mathrm{C}\right)$ and chill-stressed $\left(18{ }^{\circ} \mathrm{C}\right.$ and $\left.12{ }^{\circ} \mathrm{C}\right)$ rice seedlings after $0 \mathrm{~h}, 0.5 \mathrm{~h}, 12 \mathrm{~h}$, and $48 \mathrm{~h}$ greening. Six day old etiolated seedlings were treated with $18{ }^{\circ} \mathrm{C}$ or $12{ }^{\circ} \mathrm{C}$ cold stress. Seedlings were harvested at $0 \mathrm{~h}, 0.5 \mathrm{~h}, 12 \mathrm{~h}$, and $48 \mathrm{~h}$ of greening and their DW, protein, chlorophyll, and carotenoid contents were measured. The error bars represent standard deviations of three independent biological replicates. Different letters indicate significantly different at $p<0.05$ according to Duncan's multiple range tests.

\subsection{Effect of Chilling Stress on the Accumulation of Chlorophyll Intermediates in Rice Seedlings} during Greening

To explore how chilling stress inhibits chlorophyll biosynthesis in rice seedlings during greening, the accumulation of chlorophyll intermediates was measured.

ALA is the first intermediate of chlorophyll biosynthesis. As shown in Figure 3A, light promoted ALA accumulation. After $48 \mathrm{~h}$ of light exposure, ALA contents were $19.4 \%$ lower at $18^{\circ} \mathrm{C}$ and $46.8 \%$ lower at $12{ }^{\circ} \mathrm{C}$ compared with those at $28^{\circ} \mathrm{C}$. These results indicate that chilling stress inhibited the synthesis of ALA during greening.

PBG content at $28^{\circ} \mathrm{C}$ was increased by $14.8 \%, 104.9 \%$, and $155.2 \%$ after $0.5 \mathrm{~h}, 12 \mathrm{~h}$, and $48 \mathrm{~h}$ of light exposure, respectively (Figure 3B), and there was no significant difference of PBG content between chill-treated rice seedlings and the control seedlings after $12 \mathrm{~h}$ and $48 \mathrm{~h}$ of greening. Urogen III and coprogen III levels were significantly increased at $28^{\circ} \mathrm{C}$ during greening (Figure 3C,D). Under low temperatures, the contents of urogen III and coprogen III during greening were higher than those at $28^{\circ} \mathrm{C}$. Proto IX level was gradually decreased after exposure to light, and the rate of decline was accelerated under low temperatures (Figure 3E). 


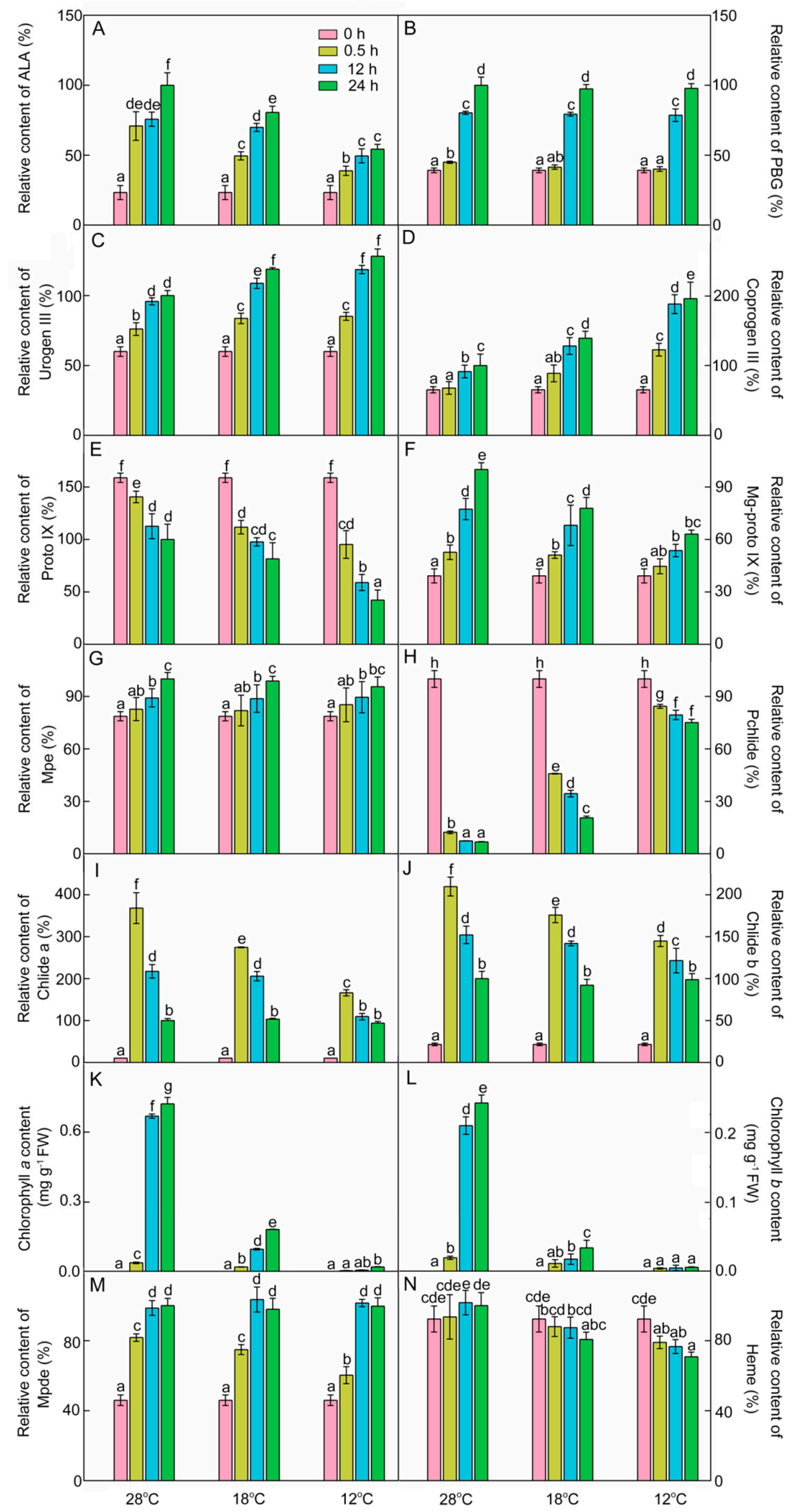


Figure 3. Chlorophyll biosynthesis intermediates during the greening period. $\delta$-Amino levulinic acid (ALA, A), porphobilinogen (PBG, B), uroporphyrinogen III (urogen III, C), coproporphyrinogen III (coprogen III, D), protoporphyrin IX (Proto IX, E), Mg-protoporphyrin IX (Mg-proto IX, F), Mg-protoporphyrin monomethyl ester (Mpe, G), protochlorophyllide (Pchlide, H), chlorophyllide $a$ (Chlide $a$, I), chlorophyllide $b$ (Chlide $b, \mathbf{J})$, chlorophyll $a(\mathrm{Chl} a, \mathbf{K})$, chlorophyll $b(\mathrm{Chl} b, \mathbf{L})$, Mg-protoporphyrin IX diester (Mpde, $\mathbf{M})$, and heme $(\mathbf{N})$ content of control $\left(28^{\circ} \mathrm{C}\right)$ and cold-stressed $\left(18^{\circ} \mathrm{C}\right.$ and $\left.12{ }^{\circ} \mathrm{C}\right)$ rice seedlings after $0 \mathrm{~h}, 0.5 \mathrm{~h}, 12 \mathrm{~h}$, and $48 \mathrm{~h}$ greening. Six day old etiolated seedlings were treated with $18{ }^{\circ} \mathrm{C}$ or $12{ }^{\circ} \mathrm{C}$ cold stress. Seedlings were harvested at $0 \mathrm{~h}, 0.5 \mathrm{~h}, 12 \mathrm{~h}$, and $48 \mathrm{~h}$ of greening and their chlorophyll biosynthesis intermediates contents were measured. The relative content of intermediates at $28{ }^{\circ} \mathrm{C}$ after $48 \mathrm{~h}$ of light exposure was defined as $100 \%$, except Pchlide; the relative content of Pchlide at $0 \mathrm{~h}$ was defined as $100 \%$ due to its massive accumulation in the dark. The error bars represent standard deviations of three independent biological replicates. Different letters indicate significantly different at $p<0.05$ according to Duncan's multiple range tests.

Mg-proto IX is the first intermediate of the $\mathrm{Mg}$ branch in the chlorophyll biosynthesis pathway. As shown in Figure 3F, Mg-proto IX increased by 34.5\%, 97.5\%, and 155.3\% after 0.5 h, 12 h, and $48 \mathrm{~h}$ of light exposure at $28{ }^{\circ} \mathrm{C}$, respectively. However, the level of $\mathrm{Mg}$-proto IX was significantly decreased during greening under the cold condition. These results demonstrated that chilling stress also inhibited the synthesis of Mg-proto IX during greening. Mg-Proto monomethyl ester (Mpe) content was increased during greening, and was barely influenced by the low temperature (Figure 3G).

In the dark, massive amounts of Pchlide were accumulated, because the protochlorophyllide oxidoreductase (POR) in angiosperms is strictly light-dependent. The etiolated rice seedlings accumulated plenty of Pchlide (Figure 3H). The content of Pchlide was drastically decreased at $28^{\circ} \mathrm{C}$ after $0.5 \mathrm{~h}$ of light exposure, while Chlide a and Chlide $\mathrm{b}$ contents were increased rapidly and then decreased during greening (Figure 3I,J). Compared with $28^{\circ} \mathrm{C}$, the levels of Pchlide were higher but the Chlide a and Chlide b contents were lower in chill-treated groups after $0.5 \mathrm{~h}$ and $12 \mathrm{~h}$ of light exposure. Obviously, the cold treatment lowered the conversion efficiency of Pchlide to Chlide, especially at $12{ }^{\circ} \mathrm{C}$.

The contents of $\mathrm{Chl} a$ and $\mathrm{Chl} b$ were almost undetectable in etiolated seedlings (Figure 3K,L), which were significantly increased at $28{ }^{\circ} \mathrm{C}$ during greening. Under low temperatures, the synthesis of $\mathrm{Chl} a$ and $\mathrm{Chl} b$ was significantly suppressed during greening, especially at $12{ }^{\circ} \mathrm{C}$. The $\mathrm{Chl} a$ and $\mathrm{Chl} b$ contents at $12{ }^{\circ} \mathrm{C}$ showed little difference from those in the dark. These results suggested that chilling stress greatly inhibited the synthesis of $\mathrm{Chl} a$ and $\mathrm{Chl} b$ during greening.

Mpe can also convert to Mg-protoporphyrin IX diester (Mpde) and then further form Chlide a ester. Mpde contents at both $28{ }^{\circ} \mathrm{C}$ and low temperatures were increased during greening (Figure $3 \mathrm{M}$ ). Heme is the product of the Fe branch, which usually acts as a cofactor in respiration and photosynthesis. Heme contents at different time points had no significant difference during greening (Figure $3 \mathrm{~N}$ ). However, the contents of heme after $48 \mathrm{~h}$ of light exposure were decreased by $19.3 \%$ and $29.2 \%$ at $18{ }^{\circ} \mathrm{C}$ and $12{ }^{\circ} \mathrm{C}$, respectively. These results also indicate that chilling stress inhibited the pathway of $\mathrm{Fe}^{2+}$ branch during greening.

In summary, the inhibition of chlorophyll biosynthesis under chilling stress may be attributed to inhibited synthesis of ALA and hampered conversion from Pchlide into Chls.

\subsection{Effect of Chilling Stress on Enzyme Activities in Chlorophyll Biosynthesis}

To further investigate the inhibitory mechanism of chlorophyll biosynthesis, we next examined some key enzymes involved in chlorophyll biosynthesis. Enzymatic activity of glutamate-1-semialdehyde transaminase (GSA-AT), which catalyzes glutamate-1-semialdehyde to ALA, was significantly increased at $28^{\circ} \mathrm{C}$ and $18{ }^{\circ} \mathrm{C}$ (Figure 4A) during greening. However, low temperature decreased GSA-AT activity, and the activity of GSA-AT at $12{ }^{\circ} \mathrm{C}$ had no significant difference from that recorded in the dark (Figure 4A). ALA dehydratase (ALAD) activity was slightly increased after light exposure, and chilling stress had no significant effect on ALAD activity during 
greening (Figure 4B). Mg-chelatase is a key enzyme which initiates the Mg branch of the chlorophyll biosynthesis pathway. Mg-chelatase activity was increased during greening, and chilling stress had an inhibitory effect on the activity of Mg-chelatase (Figure 4C). POR is a light-dependent enzyme in angiosperms that converts Pchlide to Chlide. POR activity went down gradually during greening (Figure 4D) and chill-treated seedlings showed lower POR activities, especially at $12{ }^{\circ} \mathrm{C}$. In short, the lower ALA content might be attributable to the fact that cold stress inhibited GSA-AT activity, and the inhibition of conversion from Pchlide into Chlide might have been due to the low POR activity under chilling stress.
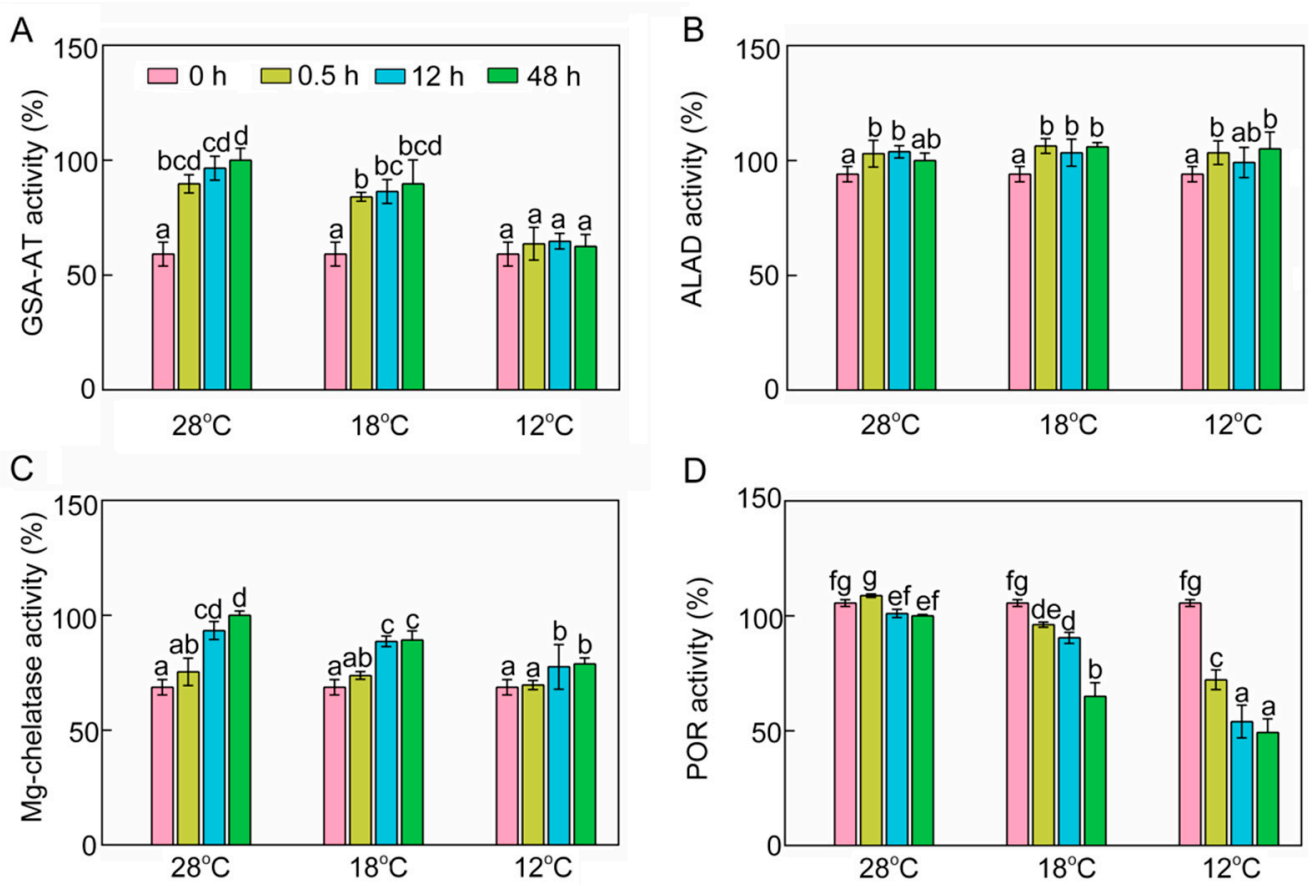

Figure 4. Effects of chilling stress $\left(18{ }^{\circ} \mathrm{C}\right.$ and $\left.12{ }^{\circ} \mathrm{C}\right)$ on activities of enzymes involved in chlorophyll biosynthesis. Glutamate-1-semialdehyde transaminase (GSA-AT, A), ALA dehydratase (ALAD, B), Mg-chelatase (C), protochlorophyllide oxidoreductase (POR, D) activities of control $\left(28^{\circ} \mathrm{C}\right)$ and chill-stressed $\left(18^{\circ} \mathrm{C}\right.$ and $\left.12{ }^{\circ} \mathrm{C}\right)$ rice seedlings after $0 \mathrm{~h}, 0.5 \mathrm{~h}, 12 \mathrm{~h}$, and $48 \mathrm{~h}$ greening. Six day old etiolated seedlings were treated with $18{ }^{\circ} \mathrm{C}$ or $12{ }^{\circ} \mathrm{C}$ chilling stress. Seedlings were harvested at $0 \mathrm{~h}$, $0.5 \mathrm{~h}, 12 \mathrm{~h}$, and $48 \mathrm{~h}$ of greening and their activities of enzymes involved in chlorophyll biosynthesis were measured. The activities of enzymes at $28{ }^{\circ} \mathrm{C}$ after $48 \mathrm{~h}$ of light exposure were defined as $100 \%$. Values are means \pm SD from three independent biological replicates. Different letters indicate significant differences according to Duncan's multiple range tests at $p<0.05$. Each data point is the average of three replicates. The error bars represent SD.

\subsection{Effect of Chilling Stress on Transcriptional Expression of Chlorophyll Biosynthetic Genes}

To decipher the effects of chilling stress on transcription levels of chlorophyll biosynthetic genes, we analyzed the relative expression of four key chlorophyll biosynthetic genes by RT-qPCR. At $28^{\circ} \mathrm{C}$, the expression of HEMA was increased initially, and then decreased after $12 \mathrm{~h}$ of light exposure (Figure 5A). This phenomenon might have been due to avoidance of the oxidative stress caused by excessive tetrapyrrole intermediate accumulation. However, the chilling stressed rice seedlings accumulated more transcript of $H E M A$ after $12 \mathrm{~h}$ of light exposure. At $28^{\circ} \mathrm{C}$, the RNA of $C H L H$ after $0.5 \mathrm{~h}$ of light exposure was slightly higher than that in etiolated seedlings, but the expression of $\mathrm{CHLH}$ was much higher at $18{ }^{\circ} \mathrm{C}$ (Figure 5B). The expression of most chlorophyll biosynthetic genes was inhibited in the dark, but $P O R A$ transcripts accumulated in the etiolated seedlings but were degraded rapidly upon illumination (Figure 5C). In contrast, $P O R B$ mRNA level did not fluctuate at $28^{\circ} \mathrm{C}$ after illumination. Interestingly, the mRNA level of $P O R B$ was very high at $18^{\circ} \mathrm{C}$ and significantly lowered 
at $12{ }^{\circ} \mathrm{C}$ (Figure 5D). The expression of DVR increased at $28^{\circ} \mathrm{C}$ and $18{ }^{\circ} \mathrm{C}$ after $12 \mathrm{~h}$ of light irradiation, but at $12^{\circ} \mathrm{C}$ it had no significant difference from that in the dark (Figure 5E). When the temperature was below $18^{\circ} \mathrm{C}$, the expressions of $C H L H, P O R B$, and $D V R$ were severely repressed. Taken together, the repressed expression of chlorophyll biosynthetic genes might be responsible for the inhibition of chlorophyll biosynthesis under low temperatures.
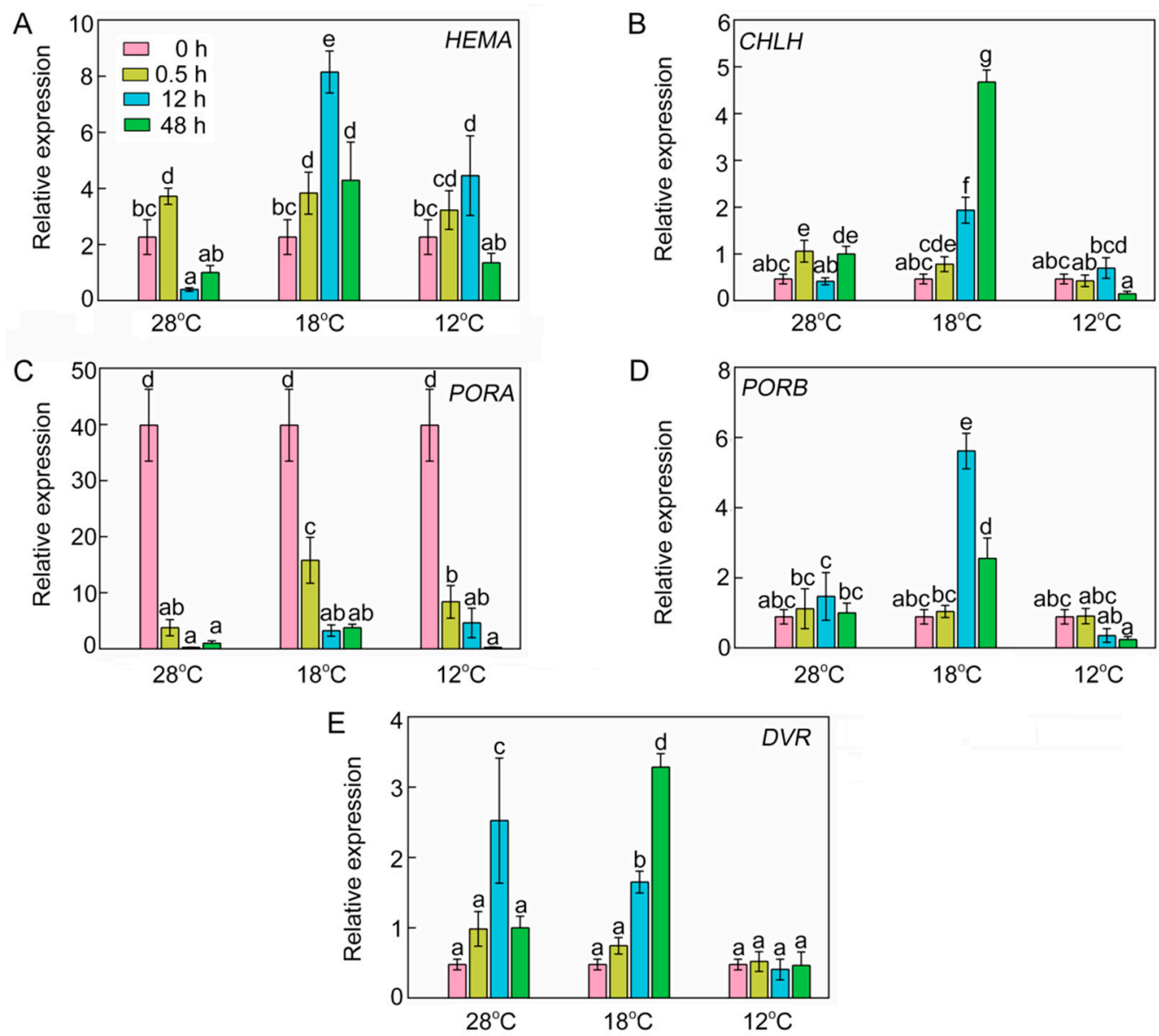

Figure 5. Effect of chilling stress on relative expression of chlorophyll biosynthetic genes HEMA (A), CHLH (B), PORA (C), PORB (D), and DVR (E). The expression levels of genes at $28{ }^{\circ} \mathrm{C}$ after $48 \mathrm{~h}$ of light exposure were set to 1 . OsACTIN1 was used as an internal standard. Values are means \pm SD from three independent biological replicates. Different letters indicate significant differences according to Duncan's multiple range tests $(p<0.05)$.

\subsection{Effect of Chilling Stress on Plastid Proteins during Greening}

To determine whether chilling stress affected plastid protein biosynthesis, immunoblotting analysis was performed (Figure 6). SDS-PAGE showed that the proteins with molecular weight from $20 \mathrm{kDa}$ to $35 \mathrm{kDa}$ under low temperatures were much lower than those at $28^{\circ} \mathrm{C}$ after $12 \mathrm{~h}$ and $48 \mathrm{~h}$ of light irradiation (Figure 6C). In etiolated seedlings, PSI (Lhca1, Lhca2, Lhca3, Lhca4, and PsaD) and PSII (D1, D2, CP43, Lchb1, Lchb2, Lchb3, Lchb4, Lchb5, and Lchb6) proteins were undetected, and large amounts of PSI and PSII proteins were rapidly synthesized at $28^{\circ} \mathrm{C}$ during greening (Figure 6A,B). Chilling stress inhibited the accumulation of PSI and PSII proteins during greening (Figure 6A,B, Supplementary Figures S1 and S2), especially at $12{ }^{\circ} \mathrm{C}$, where we hardly detected PSI and PSII proteins. 
A
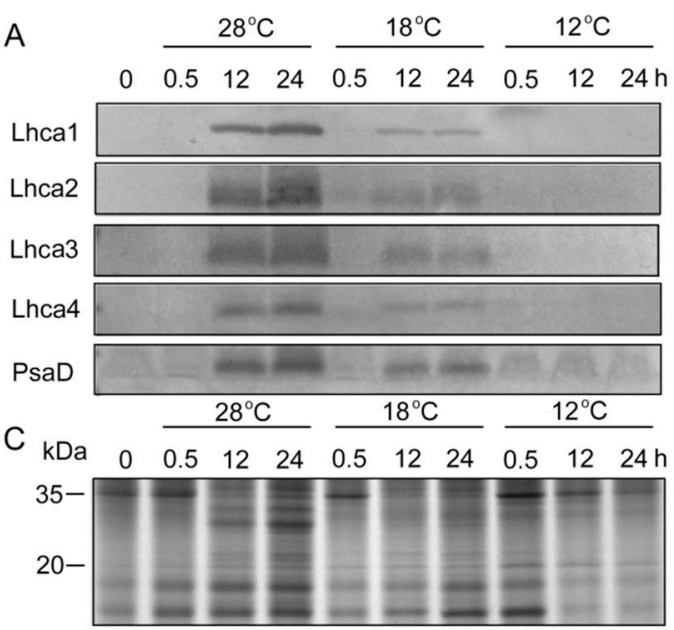

B

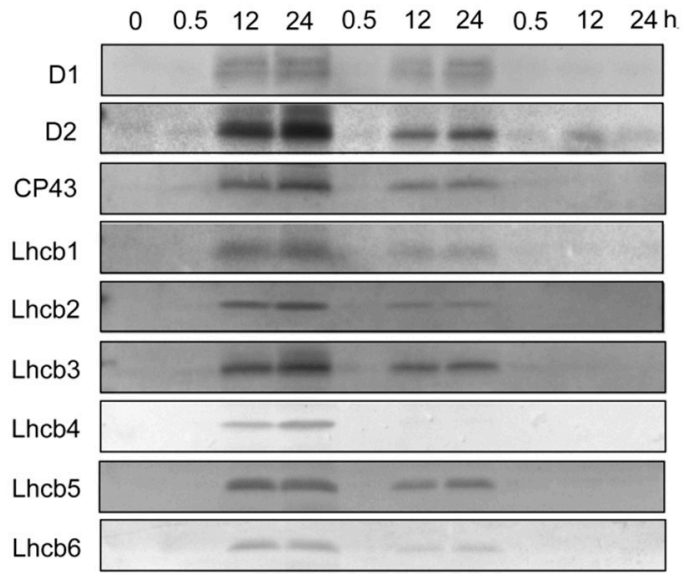

Figure 6. Immunoblot analysis of thylakoid proteins in control and chill-stressed rice seedlings. Six day old etiolated seedlings were treated with $18^{\circ} \mathrm{C}$ or $12{ }^{\circ} \mathrm{C}$ chilling stress. Thylakoid proteins were isolated from control and chill-stressed seedlings after $0 \mathrm{~h}, 0.5 \mathrm{~h}, 12 \mathrm{~h}$, and $48 \mathrm{~h}$ of greening. Immunoblot analyses were performed with antibodies specific for representative photosystem I (PSI) (A) and photosystem II (PSII) (B). The SDS-PAGE of 20 ug plastid protein stained by Coomassie blue (C).

\subsection{Effect of Chilling Stress on Chloroplast Biogenesis during Greening}

Chloroplast biogenesis normally depends on a stable supply and correct stoichiometry of chlorophyll and photosynthetic proteins during greening. To further investigate the effect of low temperature on plastid development, plastid morphology was analyzed via transmission electron microscopy (TEM). The results showed that the proplastid developed into the etioplast that contains the prolamellar bodies (PLBs) in etiolated seedlings (Figure 7A). When seedlings were illuminated $\left(120 \mu \mathrm{mol} \mathrm{m} \mathrm{m}^{-2} \mathrm{~s}^{-1}\right)$ for $48 \mathrm{~h}$ at $28^{\circ} \mathrm{C}$, PLBs disappeared and thylakoids formed and grana thylakoids stacked regularly (Figure 7B). Grana stacking was inhibited and thylakoids were much looser at $18{ }^{\circ} \mathrm{C}$ (Figure 7C), and no functional thylakoid structure was formed after $48 \mathrm{~h}$ of greening at $12^{\circ} \mathrm{C}$ (Figure 7D). Taken together, these results suggest that chilling stress inhibited the biogenesis of chloroplast, which might have been due to the lack of chlorophylls and photosynthetic proteins.

Chlorophyll fluorescence is an important indicator of the work status of chloroplasts. Compared with the seedlings grown under low temperature, the seedlings at $28^{\circ} \mathrm{C}$ showed higher quantitative values of maximum PSII yield (Fv/Fm) and lower non-photochemical quenching (NPQ) (Figure 8). Minimal fluorescence yield $\left(\mathrm{F}_{0}\right)$ showed no big fluctuations between $28^{\circ} \mathrm{C}, 18^{\circ} \mathrm{C}$, and $12^{\circ} \mathrm{C}$ treatments, but maximal fluorescence yield (Fm) was significantly lower in the chill-stressed seedlings. 

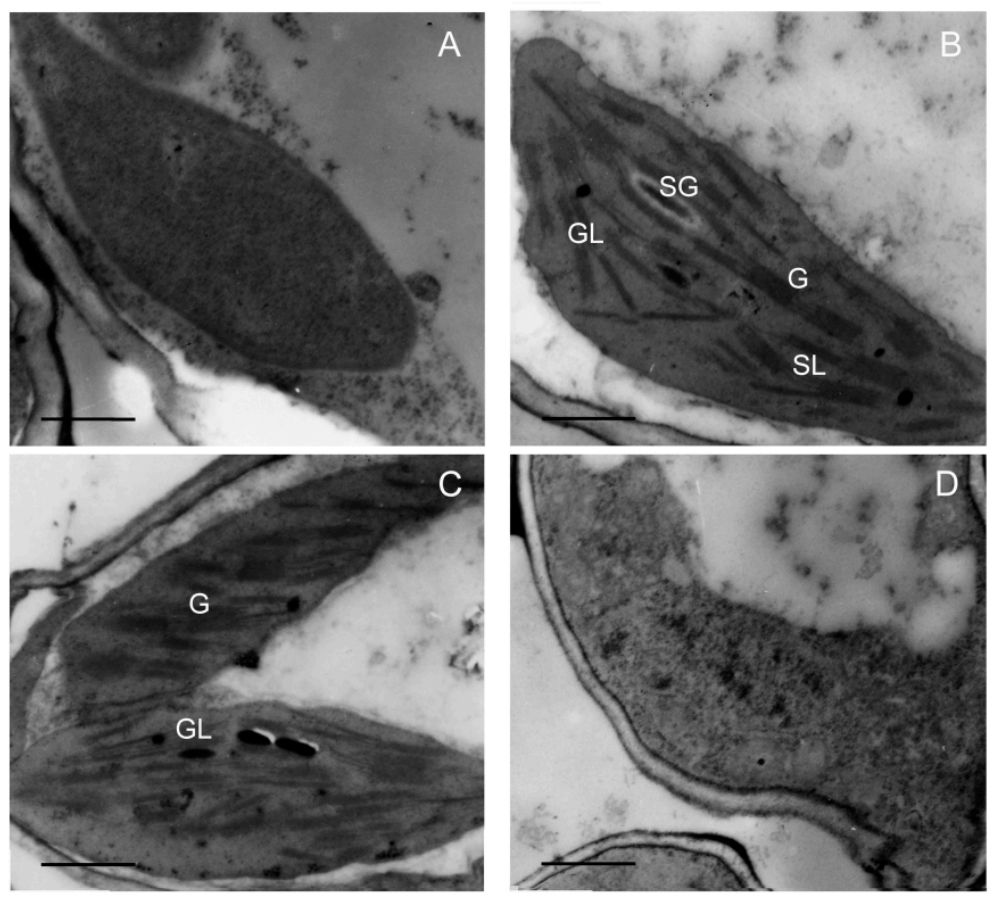

Figure 7. Effect of chilling stress $\left(18^{\circ} \mathrm{C}\right.$ and $\left.12{ }^{\circ} \mathrm{C}\right)$ on chloroplast biogenesis of rice seedlings. Plastid ultrastructure of etiolated seedlings (A); chloroplast ultrastructure after $48 \mathrm{~h}$ of greening under normal temperature $\left(28{ }^{\circ} \mathrm{C}\right)$ condition $(\mathbf{B})$; chloroplast ultrastructure after $48 \mathrm{~h}$ of greening at $18{ }^{\circ} \mathrm{C}(\mathrm{C})$; chloroplast ultrastructure after $48 \mathrm{~h}$ of greening at $12{ }^{\circ} \mathrm{C}$ (D). G: granum; SL: stroma lamellae; GL: grana lamellae; SG: starch grain. Bar $=1 \mu \mathrm{m}$.

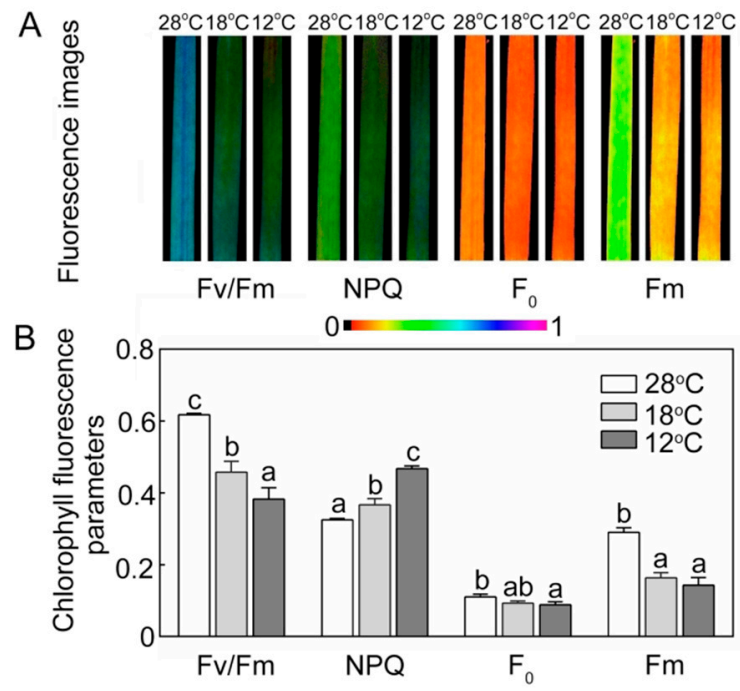

Figure 8. Effect of chilling stress on chlorophyll fluorescence parameters of rice seedlings. The chlorophyll fluorescence images (A) and chlorophyll fluorescence parameters (Fv/Fm, NPQ, $\left.\mathrm{F}_{0}, \mathrm{Fm}\right)(\mathrm{B})$ after $48 \mathrm{~h}$ of greening. Six day old etiolated seedlings were treated with $18{ }^{\circ} \mathrm{C}$ or $12{ }^{\circ} \mathrm{C}$ chilling stress. Values are means \pm SD from three independent biological replicates. Different letters indicate significant differences according to Duncan's multiple range tests $(p<0.05)$.

\subsection{Effect of Chilling Stress on ROS Accumulation, Oxidation, and Electrolyte Leakage during Greening}

As crucial indexes of oxidative damages under chilling stress, the contents of hydrogen peroxide $\left(\mathrm{H}_{2} \mathrm{O}_{2}\right)$, superoxide anion radical $\left(\mathrm{O}_{2}{ }^{-}\right)$, and malondialdehyde (MDA) were determined. Histochemical detection and quantification analysis showed that $\mathrm{H}_{2} \mathrm{O}_{2}$ increased slightly, but the superoxide anion radical $\left(\mathrm{O}_{2} \cdot{ }^{-}\right)$levels remained almost stable at $28^{\circ} \mathrm{C}$ during greening. An ROS burst occurred in 
chill-treated leaves, especially at $12{ }^{\circ} \mathrm{C}$ (Figure 9A-D), indicating that chilling stress could induce ROS accumulation. MDA content and electrolyte leakage (EL) were quantified to examine the lipid peroxidation and the damage to cellular membranes. MDA had a slight increase and EL had no remarkable change at $28^{\circ} \mathrm{C}$ during greening, but both MDA and EL significantly increased under low temperatures during greening, especially at $12{ }^{\circ} \mathrm{C}$ (Figure 9E,F). These results indicate that chilling stress induced ROS accumulation and caused lipid peroxidation and finally destroyed the integrity of membranes during greening.
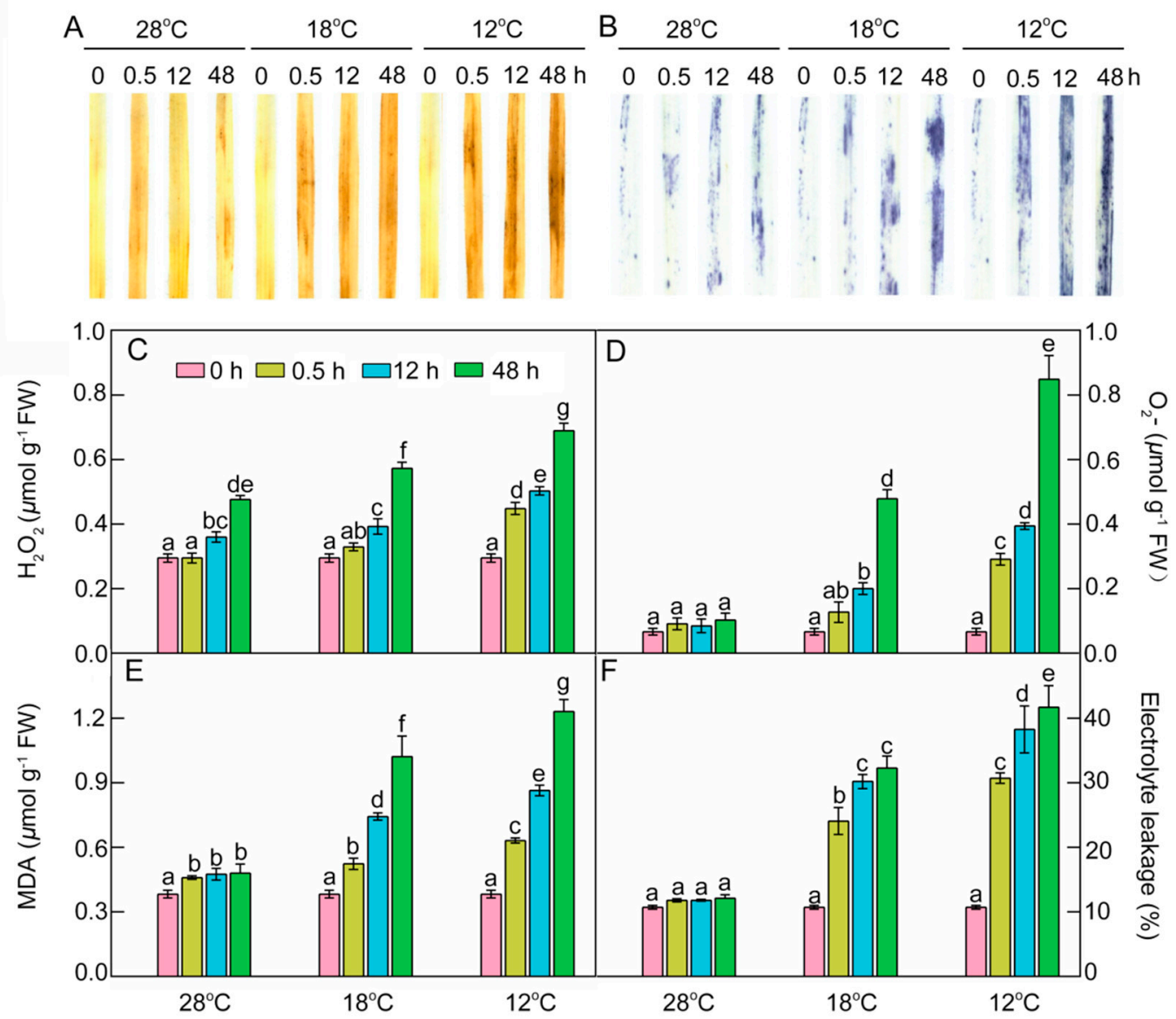

Figure 9. Effects of chill-stressed $\left(18^{\circ} \mathrm{C}\right.$ and $\left.12{ }^{\circ} \mathrm{C}\right)$ on $\mathrm{H}_{2} \mathrm{O}_{2}(\mathbf{A}, \mathbf{C}), \mathrm{O}_{2} \cdot{ }^{-}(\mathbf{B}, \mathbf{D})$, MDA content (E), and $\mathrm{EL}(\mathbf{F})$ of rice seedlings. Histochemical detection $(\mathbf{A}, \mathbf{B})$, content of $\mathrm{H}_{2} \mathrm{O}_{2}(\mathbf{C}), \mathrm{O}_{2}{ }^{-}(\mathbf{D}), \mathrm{MDA}(\mathbf{E})$, and EL (F) of control $\left(28^{\circ} \mathrm{C}\right)$ and chill-stressed $\left(18^{\circ} \mathrm{C}\right.$ and $\left.12^{\circ} \mathrm{C}\right)$ rice seedlings after $0 \mathrm{~h}, 0.5 \mathrm{~h}, 12 \mathrm{~h}$, and $48 \mathrm{~h}$ greening. Six day old etiolated seedlings were treated with $18^{\circ} \mathrm{C}$ or $12{ }^{\circ} \mathrm{C}$ chilling stress. Seedlings were harvested at $0 \mathrm{~h}, 0.5 \mathrm{~h}, 12 \mathrm{~h}$, and $48 \mathrm{~h}$ of greening and their ROS levels were measured. Values are means \pm SD from three independent biological replicates. Different letters indicate significant differences according to Duncan's multiple range tests $(p<0.05)$.

\subsection{Effect of Chilling Stress on Cell Death during Greening}

We further examined the effect of low temperature on cell death of leaves using Trypan-blue staining (Figure 10). Few cells could be stained at $28^{\circ} \mathrm{C}$, but the number of dead cells significantly increased under low temperatures during greening, especially at $12{ }^{\circ} \mathrm{C}$. These results indicate that the low temperature aggravated cell death during greening. 


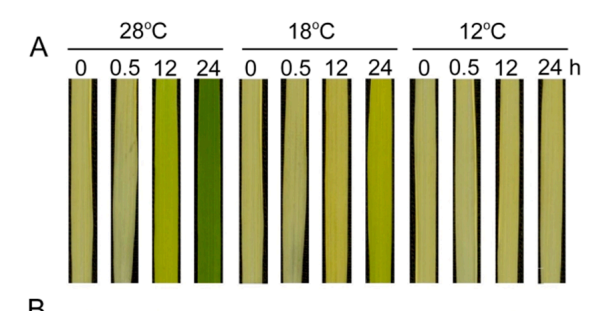

B

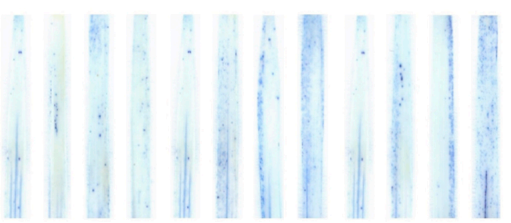

Figure 10. Effect of chilling stress on cell death of rice seedlings. Six day old etiolated seedlings were treated with $18{ }^{\circ} \mathrm{C}$ or $12{ }^{\circ} \mathrm{C}$ chilling stress. Phenotypes of rice leaves at different time points (A); Trypan-blue staining $(\mathbf{B})$ of control $\left(28^{\circ} \mathrm{C}\right)$ and chill-stressed $\left(18^{\circ} \mathrm{C}\right.$ and $\left.12{ }^{\circ} \mathrm{C}\right)$ leaves after $0 \mathrm{~h}, 0.5 \mathrm{~h}$, $12 \mathrm{~h}$, and $48 \mathrm{~h}$ greening.

\subsection{Effect of Chilling Stress on Epidermis of Rice Leaves during Greening}

To investigate whether low temperature affected the epidermal characteristics, we observed the epidermis cells after $48 \mathrm{~h}$ of greening. The upper and lower epidermis layers of rice are mainly composed of stomata apparatus and epidermis cells. In addition, there were some trichomes. The shapes and sizes of upper and lower epidermis cells showed no significant difference between the seedlings at $28^{\circ} \mathrm{C}$ and low temperatures (Figure 11), while stomata under low temperature were smaller than those at $28{ }^{\circ} \mathrm{C}$ (Table 1). Meanwhile, chilling stress had no significant effect on the number of trichomes (Table 1).
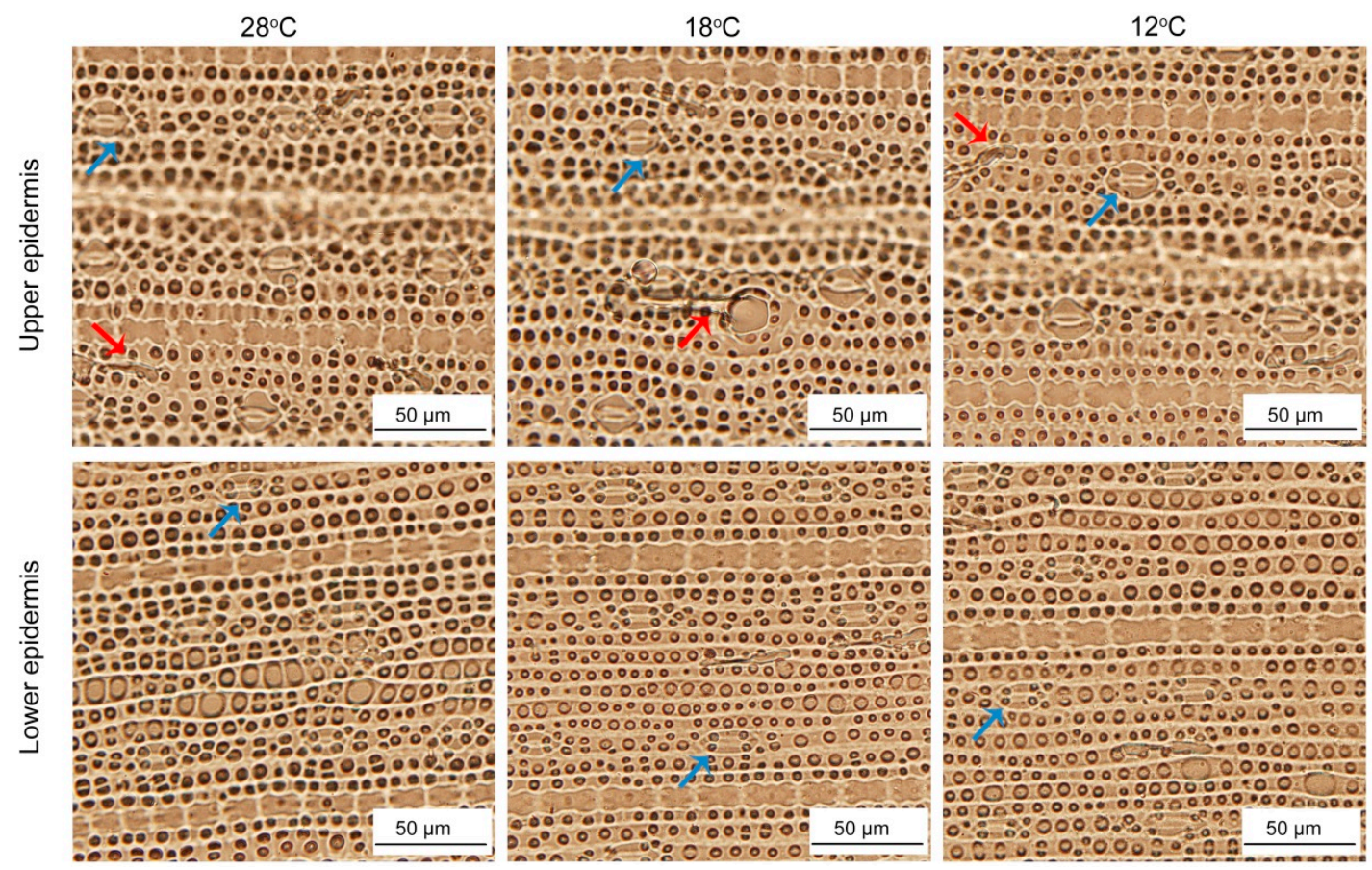

Figure 11. The epidermis cells development of control and chill-stressed rice leaves. Six day old etiolated seedlings were treated with $18^{\circ} \mathrm{C}$ or $12{ }^{\circ} \mathrm{C}$ chilling stress. Seedlings were harvested at $48 \mathrm{~h}$ of greening and their epidermal cells' characteristics were observed. Red arrows and blue arrows represent trichomes and stoma, respectively. 
Table 1. Effect of chilling stress on stomatal characteristics and trichomes number of rice seedlings.

\begin{tabular}{ccccccc}
\hline & Type of Leaf & $\begin{array}{c}\text { Stomata } \\
\text { Length }(\boldsymbol{\mu m})\end{array}$ & $\begin{array}{c}\text { Stomata } \\
\text { Width }(\boldsymbol{\mu m})\end{array}$ & $\begin{array}{c}\text { Stomata Size } \\
\left(\boldsymbol{\mu \mathbf { m } ^ { 2 } )}\right.\end{array}$ & $\begin{array}{c}\text { Stomata Density } \\
\left(\mathbf{N o} \cdot \mathbf{m m}^{-2}\right)\end{array}$ & $\begin{array}{c}\text { Trichomes } \\
(\text { Per Unit leaf) }\end{array}$ \\
\hline \multirow{2}{*}{$28^{\circ} \mathrm{C}$} & Upper epidermis & $27.50 \pm 3.28 \mathrm{a}$ & $18.40 \pm 1.23 \mathrm{a}$ & $384.32 \pm 24.75 \mathrm{a}$ & $195.51 \pm 14.97 \mathrm{bc}$ & $49.61 \pm 10.63 \mathrm{a}$ \\
& Lower epidermis & $21.92 \pm 1.73 \mathrm{c}$ & $15.60 \pm 1.34 \mathrm{~b}$ & $307.98 \pm 20.86 \mathrm{~b}$ & $210.94 \pm 25.69 \mathrm{a}$ & $48.51 \pm 6.91 \mathrm{a}$ \\
\multirow{2}{*}{$18^{\circ} \mathrm{C}$} & Upper epidermis & $23.43 \pm 1.44 \mathrm{~b}$ & $15.32 \pm 1.74 \mathrm{~b}$ & $303.59 \pm 20.76 \mathrm{bc}$ & $193.67 \pm 16.56 \mathrm{bc}$ & $52.18 \pm 10.08 \mathrm{a}$ \\
\multirow{2}{*}{$12{ }^{\circ} \mathrm{C}$} & Lower epidermis & $21.80 \pm 1.52 \mathrm{c}$ & $13.66 \pm 1.08 \mathrm{c}$ & $294.31 \pm 16.00 \mathrm{c}$ & $206.53 \pm 30.24 \mathrm{ab}$ & $51.45 \pm 10.11 \mathrm{a}$ \\
& Upper epidermis & $23.19 \pm 1.62 \mathrm{~b}$ & $13.57 \pm 0.89 \mathrm{c}$ & $299.30 \pm 17.94 \mathrm{bc}$ & $184.12 \pm 22.68 \mathrm{c}$ & $51.08 \pm 9.38 \mathrm{a}$ \\
& Lower epidermis & $22.62 \pm 1.62 \mathrm{c}$ & $13.63 \pm 0.91 \mathrm{c}$ & $270.20 \pm 26.74 \mathrm{~d}$ & $195.88 \pm 14.94 \mathrm{bc}$ & $51.45 \pm 5.33 \mathrm{a}$ \\
\hline
\end{tabular}

The values are expressed as mean \pm SD $(n=50)$; different letters represent significant difference $(p<0.05)$.

\section{Discussion}

Chlorophyll biosynthesis is affected by various biotic and abiotic factors. Previous studies have reported that water and salt stresses lead to the severe inhibition of chlorophyll biosynthesis during de-etiolation $[1,30]$. Temperature is one of the major environmental factors that can inhibit chlorophyll biosynthesis and chloroplast biogenesis, and thus affect photosynthesis [31-33]. Our previous study also showed that cold stress dramatically decreases the net photosynthetic rate, stomatal conductance, intercellular $\mathrm{CO}_{2}$ concentration, and water use efficiency in rice seedlings [34]. In this study, our results demonstrated that chlorophyll was significantly increased with the period of light exposure during greening at $28{ }^{\circ} \mathrm{C}$ (Figure 2C). However, chlorophyll biosynthesis was obviously inhibited in chill-stressed rice seedlings. Our study further found that ALA synthesis was significantly inhibited in chill-stressed seedlings (Figure 3A). That is to say, the early step of chlorophyll biosynthesis was inhibited by the low temperature, which ultimately led to a significant reduction of chlorophyll and heme contents. Similar changes have also been observed in water- and salt-stressed rice/wheat seedlings during early seedling development $[1,30]$. Meanwhile, GSA-AT activity was reduced by low temperature during de-etiolation (Figure 4A), suggesting that decreased ALA synthesis in chill-stressed rice seedlings might have been due to the downregulated GSA-AT activity.

In the whole chlorophyll synthesis process, Mg-proto IX and Chlide levels were reduced significantly in stressed seedlings (Figure 3F,I,J), and Mg-chelatase and POR activities were decreased synchronously in chill-stressed seedlings (Figure 4C,D). Declines in Mg-chelatase and POR activities were also observed in water-stressed rice [1]. In plants, $\mathrm{Mg}$-chelatase is composed of three non-identical subunits that are encoded by $C H L I, C H L D$, and $C H L H[35,36]$. Previous studies have demonstrated that the mutations of Chl1 and Chl9 genes which encode CHLD and CHLI could reduce Mg-chelatase activity, and thus inhibit chlorophyll synthesis [37]. Additionally, ATP is required for the catalytic activity of Mg-chelatase, while ferrochelatase is inhibited by ATP. More Pchlide is allocated to the $\mathrm{Mg}$ branch when ATP levels are higher in the light; conversely, the Mg branch is inhibited in the dark [8]. In addition, we found that $\mathrm{CHLH}$ expression level was much higher at $18^{\circ} \mathrm{C}$ than that at $28{ }^{\circ} \mathrm{C}$, but its expression was the lowest at $12{ }^{\circ} \mathrm{C}$. $\mathrm{CHLH}$ expression in etiolated seedlings was suppressed with lower histone acetylation levels by PIF3, but increased rapidly during greening with higher acetylation levels of histones [38]. Chilling stress might repress histone acetylation levels of $\mathrm{CHLH}$ at $12^{\circ} \mathrm{C}$. Numerous studies have indicated that post-translational regulation plays an essential role in chlorophyll biosynthesis [39-41]. The caseinolytic protease activity counteracts the binding of GluTR-binding protein to assure an appropriate content of GluTR and an adequate ALA synthesis at the post-translational level [42]. This might be why the increased transcriptional levels of $D V R$ and $\mathrm{CHLH}$ under chilling stress were not directly proportional to their corresponding products (Figures 2 and 5). Previous studies have also shown that in water- and chill-stressed rice/cucumber seedlings, Mg-chelatase activity and its gene/protein expression were downregulated [1,43]. The light-dependent POR is a plastid (pro)thylakoid-membrane-associated protein, which binds to NADPH and Pchlide to form a ternary complex in etioplasts [44]. There are three POR isoenzymes in Arabidopsis thaliana. PORA transcripts accumulate in etiolated seedlings, but the expression of PORA is strongly downregulated when exposed to light. The PORB transcript can be detected throughout the growth and development 
of plants, while the expression of PORC is induced by light and is predominantly present in fully matured green tissues $[8,45]$. However, there are only two isoenzymes in rice, namely PORA and PORB [1]. In the present study, POR activity was significantly inhibited in stressed seedlings, especially at $12{ }^{\circ} \mathrm{C}$ (Figure $4 \mathrm{D}$ ). PORA transcription decreased dramatically when etiolated rice seedlings were exposed to light at $28^{\circ} \mathrm{C}$, but chill-treated rice seedlings had a relatively high PORA mRNA level (Figure 5). Similarly, POR activity and PORB transcript abundance were downregulated in water- and chill-stressed rice/cucumber seedlings [1,43]. However, we found that a slightly lowered temperature $\left(18^{\circ} \mathrm{C}\right)$ could significantly increase the expression of $P O R B$. As another important tetrapyrrole, heme content showed a $30 \%$ drop in seedlings at $12{ }^{\circ} \mathrm{C}$ compared to that at $28{ }^{\circ} \mathrm{C}$ after $24 \mathrm{~h}$ of greening (Figure $3 \mathrm{~A}$ ), which was far less than the declined proportion of chlorophylls, indicating that $\mathrm{Chl}$ biosynthesis is more sensitive to low temperatures than heme synthesis. Meanwhile, this result indicated that more tetrapyrrole metabolic intermediates were allocated to the heme branch than to the chlorophyll branch under chilling stress. Thus, the inhibition of chlorophyll biosynthesis under chilling stress might be attributable to the blocked synthesis of ALA and the inhibition of conversion from Pchlide into Chls.

It has been found that the development of thylakoid is inhibited when chlorophyll biosynthesis is reduced [37]. Chlorophyll content was decreased and thylakoid membrane was not stacked in porB por $C$ double mutants [46]. These results indicated that the inhibition of chlorophyll biosynthesis affected the biogenesis of chloroplasts, which led to the reduction of granum lamellae and thylakoid membrane proteins. Thus, a stable supply and correct stoichiometry of chlorophyll are necessary for chloroplast biogenesis. In the present study, chloroplast biogenesis was significantly affected by chilling stress (Figure $7 \mathrm{C}, \mathrm{D}$ ). The grana lamellae were disorganized at $18^{\circ} \mathrm{C}$ and no grana lamellar structure was formed at $12{ }^{\circ} \mathrm{C}$ (Figure 7D). The synthesis of thylakoid membrane protein is of importance to the assembly of the photosystem during greening. Western blotting results showed that thylakoid protein synthesis was obviously inhibited under chilling stress (Figure 6). PSII is considered a primary target of photodamage, and the D1 protein is the most vulnerable component in the PSII reaction center under stress conditions [47]. In this study, the content of D1 was obviously lower under low temperatures, and was almost undetectable at $12{ }^{\circ} \mathrm{C}$. Moreover, low temperatures greatly inhibited the content of the peripheral antenna proteins of PSII, including Lhcb1, Lhcb2, Lhcb3, Lhcb4 (CP29), Lhcb5 (CP26), and Lhcb6 (CP24) and peripheral antenna proteins of PSI, including Lhca1, Lhca2, Lhca3, Lhca4, and PsaD (Figure 6), especially at $12{ }^{\circ} \mathrm{C}$.

Chlorophyll fluorescence analysis has been proven to be a powerful method for obtaining the functional status of PSII [48]. OsAsr1 rice seedlings have a high value of Fv/Fm, which is correlated with an enhanced cold tolerance [33], suggesting that Fv/Fm could be an indicator of cold tolerance. The decline of $\mathrm{Fv} / \mathrm{Fm}$ in stressed seedlings may be due to the partial inactivation of PSII reaction centers [49]. In the present study, after $48 \mathrm{~h}$ of greening, chill-treated seedlings showed an obvious reduction of Fv/Fm (Figure 8A,B), and the lower Fv/Fm might have been because the low temperature suppressed the assembly and formation of PSII. Meanwhile, the ultrastructural changes of the plastids also indicated that chilling stress affected grana stacking and thylakoid integrity (Figure 6C,D), thereby resulting in a decrease in PSII activity in the stressed plants. Nonphotochemical quenching is a self-protection mechanism in plants. Previous studies have shown that effective heat dissipation in plants can reduce the occurrence of photoinhibition induced by stresses [49]. In this study, the increase of NPQ in stressed seedlings indicated that more excess light energy needed to be dissipated because of the low activity of PSII at low temperatures.

ROS plays double roles under cold stress. On one hand, ROS as a signal can trigger stress-responsive gene expression and the MKK6-MPK3 signaling pathway [26]. On the other hand, excessive ROS in plants can directly induce membrane lipid peroxidation, cell integrity damage, and cell death [50]. PSI and PSII in chloroplasts are the major sources of ROS in plants. Numerous studies have indicated that ROS production increases significantly in plants and the balance of ROS is disturbed under stress conditions $[49,51]$. Cold signals can be sensed by rice cells through changes in membrane rigidity 
and osmotic pressure [52]. The membrane rigidity increases under cold stress, resulting in a high electrolyte leakage $[53,54]$. In accordance with ROS accumulation, the level of lipid peroxidation (MDA) and damage to the cellular membranes were also higher under chilling stress (Figure 9E,F). The increased EL indicated the enhancement of membrane rigidification, which is required for the cold-activated SAMK signaling cascade via cytoskeleton, $\mathrm{Ca}^{2+}$ fluxes, and CDPKs [55]. Cold stress initially promotes $\mathrm{Ca}^{2+}$ influx into the cytoplasm, which might be controlled by $\mathrm{Ca}^{2+}$ channels that are activated by membrane rigidification [56]. Furthermore, the calcium signaling cascade interprets and amplifies the rice-sensing cold signal and subsequently activates the DREB-CRT/DRE pathway, which is important for the cold response [57]. At the same time, our observations showed that leaf cell death was significantly increased under the cold-stress condition during greening (Figure 10). Proline and soluble sugars served as osmoprotectants against oxidative damage, which are also considered indicators to assess the potential cold tolerance of plants [34]. Our previous study indicated that proline and soluble sugar accumulation is enhanced in cold-stressed rice seedlings [34].

Over the past decades, researchers have made extensive efforts to improve cold tolerance in crops, especially in rice. The increasing global food demand, together with rapid population growth and frequent occurrence of chilling forces scientists to speed up and push forward the improvement of rice cold tolerance. ALA synthesis is the rate-limiting step in the whole tetrapyrrole metabolic net, and it is obviously inhibited in chill-treated rice seedlings (Figure 3A). Based on this finding, we propose that application of exogenous ALA or overexpression of HEMA or GSA gene in plants may overcome inadequate chlorophyll biosynthesis and maintain the structural and functional integrity of chloroplasts, and thus improve cold tolerance. Because tetrapyrrole intermediates are easily activated by light, leading to photooxidative damage, the concentration of exogenous ALA should be applied accurately. Several investigations have recognized that ALA pretreatment enhances plants' tolerance to chilling by increasing the activities of antioxidant enzymes to eliminate excessive ROS and improving chlorophyll fluorescence and photosynthesis [58-60]. Thus, our results suggested the protective role of exogenous ALA and contribute to further illustrate its mechanism. Nevertheless, exogenous ALA increased chlorophyll accumulation in etiolated oilseed rape, but failed to enhance its cold tolerance [61]. Application of exogenous ALA is an exciting field to explore, and might be beneficial for increasing chlorophyll content and improving cold resistance of rice seedlings. Thus, more refined investigations of the effect of exogenous ALA in etiolated seedlings under chilling stress are still required.

Given that transgenic technologies have been developed intensively and almost all chlorophyll biosynthetic genes have been identified in many crops, genetically engineered crops provide a new opportunity to solve the threats from environmental stresses. Thus, genetic modification of chlorophyll biosynthetic genes might be a promising approach for improving plant cold tolerance. A previous study suggested that $C H L G$-over-expressing plants have increased ALA synthetic capacity and increased chelatase activity, indicating that overexpression of $C H L G$ could stimulate chlorophyll biosynthesis [62]. Overexpression of HEMA, DVR, and CHLG in plants may be helpful to improve the cold tolerance of rice seedlings during greening by increasing chlorophyll biosynthesis.

\section{Materials and Methods}

\subsection{Plant Material and Growth Conditions}

Rice (Oryza sativa L.) cultivar DM You 6188 was used as experimental material, and was purchased from Ya'an seed store. Seeds were sterilized with $3 \%(\mathrm{~m} / \mathrm{v})$ sodium hypochlorite for $10 \mathrm{~min}$, washed five times with distilled water and soaked in distilled water for $36 \mathrm{~h}$, then placed on moist filter papers with $1 / 4$ strength Hoagland nutrient solution and grown in the dark at $28^{\circ} \mathrm{C}$ before chilling treatment. After 6 days, the etiolated seedlings were transferred to vermiculite with $1 / 4$ strength Hoagland nutrient solution in the dark. The seedlings were then exposed to light $\left(120 \mu \mathrm{mol} \mathrm{m}{ }^{-2} \mathrm{~s}^{-1}\right)$ and transferred to $28^{\circ} \mathrm{C}, 18^{\circ} \mathrm{C}$, and $12^{\circ} \mathrm{C}$, respectively. The first leaf was used to measure physiological 
and biochemical parameters at $0 \mathrm{~h}, 0.5 \mathrm{~h}, 12 \mathrm{~h}$, and $48 \mathrm{~h}$ after exposure to light, and all experiments were repeated at least three times.

\subsection{Determination of Shoot Dry Weight (DW)}

The shoots were collected at $0 \mathrm{~h}, 0.5 \mathrm{~h}, 12 \mathrm{~h}$, and $48 \mathrm{~h}$ after being exposed to light, washed with tap water and rinsed twice with distilled water, gently wiped with a paper towel, and then oven-dried to a constant weight at $80^{\circ} \mathrm{C}$ for DW determination.

\subsection{Determination of Chlorophyll, Carotenoids and Protein}

Chlorophyll and carotenoids were extracted from $0.1 \mathrm{~g}$ fresh rice seedlings with $80 \%$ acetone. The absorbance of the extract was recorded at 663, 646, and $470 \mathrm{~nm}$ according to Lichtenthaler and Wellburn using a spectrophotometer (UV-1750, Shimadzu, Japan) [63]. Protein content was determined by the Bradford method [64].

\subsection{Determination of Chlorophyll Precursors}

$\delta$-Aminolevulinic acid (ALA) was measured according to Dei [65]. Briefly, $0.5 \mathrm{~g}$ of fresh leaf was ground in $10 \mathrm{~mL}$ of $4 \%$ trichloracetic acid with an ice bath, then centrifuged at $18,000 \times g$ for $15 \mathrm{~min}$. Next, $500 \mu \mathrm{L}$ of the supernatant was mixed with $2.35 \mathrm{~mL}$ of $1 \mathrm{~mol} / \mathrm{L}$ sodium acetate and $1.5 \mathrm{~mL}$ of acetyl-acetone. The mixture was then heated in boiling water for $10 \mathrm{~min}$. After cooling to $25^{\circ} \mathrm{C}, 2 \mathrm{~mL}$ of the mixture was added to $2 \mathrm{~mL}$ of Ehrlich-Hg and reacted in the dark for $15 \mathrm{~min}$. The absorption was recorded at $553 \mathrm{~nm}$. The content of ALA was evaluated from the calibration curve prepared from known concentration of ALA.

Porphobilinogen (PBG) was extracted as described by Bogorad [66] with some modifications. Briefly, $0.5 \mathrm{~g}$ of fresh leaf was homogenized with $5 \mathrm{~mL}$ of extraction solution $(0.6 \mathrm{~mol} / \mathrm{L}$ Tris, $0.1 \mathrm{~mol} / \mathrm{L}$ EDTA, $\mathrm{pH}$ 8.2) in an ice bath and centrifuged for $10 \mathrm{~min}$ at $18,000 \times \mathrm{g}$. Next, $2 \mathrm{~mL}$ of the mixture was mixed with $2 \mathrm{~mL}$ of Ehrlich-Hg and reacted in the dark for $15 \mathrm{~min}$, with absorbance measured at $553 \mathrm{~nm}$.

Uroporphyrinogen III (urogen III) and coproporphyrinogen III (coprogen III) were assessed according to Bogorad [66] and Rebeiz et al. [67], with some modifications. To determine urogen III content, $1.0 \mathrm{~g}$ fresh sample was extracted in an ice bath with $10 \mathrm{~mL} 0.067 \mathrm{~mol} / \mathrm{L} \mathrm{PBS} \mathrm{pH} \mathrm{6.8,} \mathrm{then}$ centrifuged for $10 \mathrm{~min}$ at $18,000 \times \mathrm{g}$. Next, $5 \mathrm{~mL}$ of the supernatant was mixed $0.25 \mathrm{~mL}$ of $1 \% \mathrm{Na}_{2} \mathrm{~S}_{2} \mathrm{O}_{3}$. The mixture was illuminated by strong light for $20 \mathrm{~min}$, after which the $\mathrm{pH}$ was adjusted to 3.5 with $1 \mathrm{~mol} / \mathrm{L}$ formic acid. The mixture was extracted three times with $5 \mathrm{~mL}$ of ether. The water phase was used to measure the absorbance at $405.5 \mathrm{~nm}$. For analysis of coprogen III, the ether phase was extracted with $0.1 \mathrm{~mol} / \mathrm{L} \mathrm{HCl}$ three times. The $\mathrm{HCl}$ phase was used to measure the absorbance at $399.5 \mathrm{~nm}$.

Protoporphyrin IX (Proto IX) was measured based on the method of Rebeiz et al. [67]. Fresh leaves (1.0) were homogenized with extracted solution (acetone: $0.1 \mathrm{~mol} / \mathrm{L} \mathrm{NH}_{3} \cdot \mathrm{H}_{2} \mathrm{O}, 9: 1, v / v$ ) in an ice bath, then centrifuged for $10 \mathrm{~min}$ at $18,000 \times \mathrm{g}$. Next, $5 \mathrm{~mL}$ of the supernatant was mixed with $2 \mathrm{~mL}$-hexane. The acetone phase was used to record the fluorescence emission spectra at 400,622, 633, and $640 \mathrm{~nm}$.

Similarly, Mg-protoporphyrin IX (Mg-proto IX), Mg-Proto monomethyl ester (Mpe), Mg-protoporphyrin IX diester (Mpde), protochlorophyllide (Pchlide), and chlorophyllide (Chlide) were determined based on their fluorescence emission spectrums [67]. Heme was extracted and quantified as described by Wilks [68].

\subsection{Measurement of Chlorophyll Biosynthetic Enzyme Activities}

Fresh leaves were collected at $0 \mathrm{~h}, 0.5 \mathrm{~h}, 12 \mathrm{~h}$, and $48 \mathrm{~h}$ after exposure to light, and immediately grounded with extracting buffers at $4{ }^{\circ} \mathrm{C}$. Glutamate 1-semialdehyde aminotransferase (GSA-AT) activity was analyzed according to Shalygo et al. [62]. ALA dehydratase (ALAD) activity was evaluated as described by Kumar et al. [43]. Mg-chelatase activity was determined based on Yaronskaya et al. [69]. POR activity was measured according to Rebeiz et al. [67]. 


\subsection{Isolation of RNA and Quantitative Real-Time PCR}

Total RNA was extracted from rice leaves using a Column Plant RNAOUT V1.0 Kit (Tiandz Inc., Beijing, China) according to the manufacturer's instructions. The first strand of cDNA was synthesized using PrimeScript ${ }^{\mathrm{TM}}$ RT reagent Kit with gDNA Eraser (Perfect Real Time) (TaKaRa Bio Inc., Dalian, China), following standard protocol. The quantitative real-time PCR was carried out with the diluted cDNA and SYBR Premix Ex Taq ${ }^{\mathrm{TM}}$ II (TaKaRa Bio Inc., Dalian, China) using CFX96 TouchTM Real-Time PCR Detection Systems (Bio-Rad, Chicago, USA), as described previously [70]. The relative expression level of OsACTIN1 was normalized. The primers used for quantitative real-time PCR are listed in Supplementary Table S1.

\subsection{Isolation of Thylakoid Proteins and Western Blotting}

Thylakoid membrane proteins were isolated as described by Fristedt et al. [71]. Isolated thylakoid membrane protein was separated by SDS-PAGE $(5 \%$ acrylamide stacking gel $+15 \%$ separation gel + $6 \mathrm{M}$ urea) [72]. Western blotting analysis was performed according to Chen et al. [73]. The primary antibodies (all raised in rabbits) including anti-Arabidopsis D1, D2, CP43, LHCb1, LHCb2, LHCb3, LHCb4, LHCb5, LHCb6, LHCa1, LHCa2, LHCa3, and LHCa4, and horseradish-peroxidase-conjugated secondary antibody were purchased from Agrisera (Umea, Sweden). The Western blotting signal was detected by a chemiluminescent detection system (ECL, GE Healthcare, Buckinghamshire, UK). The quantification of immunoblots was done with Quantity One software (Bio-Rad, Hercules, CA, United States).

\subsection{Observation of Transmission Electron Microscopy}

Transmission electron microscopy (TEM) analysis of leaves was carried out following a previous method [74]. Leaf tissue was fixed with $3 \%$ glutaraldehyde in $0.1 \mathrm{M}$ sodium cacodylate buffer ( $\mathrm{pH}$ 6.9) at $4{ }^{\circ} \mathrm{C}$ overnight, after being washed with phosphate buffer three times. Samples were post-fixed with $2.5 \%$ osmium tetroxide, then dehydrated in a gradient solution of alcohol-acetone mixture and embedded in Epon Ultrathin cross sections were cut with an ultramicrotome (Ultracut F-701704, Reichert-Jung, Reichert, Austria), which was then stained with uranyl acetate and observed using a transmission electron microscope (TEM H-9500, Itachi, Tokyo, Japan) operating at $75 \mathrm{kV}$.

\subsection{Measurement of Chlorophyll Fluorescence}

Chlorophyll fluorescence was imaged using a modulated imaging chlorophyll fluorometer (the Imaging PAM M-Series Chlorophyll Fluorometer System, Heinz-Walz Instruments, Effeltrich, Germany) according to the instructions. The rice leaves were adapted in the dark for $30 \mathrm{~min}$ prior to the fluorescence assay, and minimum fluorescence yield $\left(\mathrm{F}_{0}\right)$, maximum fluorescence yield $(\mathrm{Fm})$ and nonphotochemical quenching (NPQ), and maximal quantum yield of PSII photochemistry (Fv/Fm) were then determined according to the method of Zhou et al. [75].

\subsection{Analysis of Reactive Oxygen Species}

Histochemical staining of hydrogen peroxide $\left(\mathrm{H}_{2} \mathrm{O}_{2}\right)$ and superoxide anion radicals $\left(\mathrm{O}_{2}{ }^{-}\right)$was performed using 3, 3-diaminobenzidine (DAB) and nitro blue tetrazolium (NBT), respectively [76]. Leaf tissue was immersed in NBT $(1 \mathrm{mg} / \mathrm{mL})$ solution for $2 \mathrm{~h}$ or in DAB $(0.5 \mathrm{mg} / \mathrm{mL})$ solution for $12 \mathrm{~h}$ in the dark. The stained leaves were decolorized in boiling ethanol $(90 \%, v / v)$ for $2 \mathrm{~h} . \mathrm{H}_{2} \mathrm{O}_{2}$ was quantitated according to Velikova et al. [77] and calculated using a standard curve of $\mathrm{H}_{2} \mathrm{O}_{2}$ reagent. The quantification of $\mathrm{O}_{2}{ }^{--}$was determined as described by Nahar et al. [78] and calculated using a standard curve of a $\mathrm{NaNO}_{2}$ reagent. 


\subsection{Determination of Malondialdehyde (MDA) and Electrolyte Leakage (EL)}

The level of membrane lipid peroxidation was estimated by MDA content, which was determined by thiobarbituric acid (TBA) assay [78]. Fresh leaves $(0.5 \mathrm{~g})$ were homogenized in $5 \mathrm{~mL}$ of $5 \%(\mathrm{~m} / \mathrm{v})$ trichloroacetic acid (TCA) and centrifuged at $4{ }^{\circ} \mathrm{C}$ for $10 \mathrm{~min}$ at $8000 \times \mathrm{g}$. Next, $2 \mathrm{~mL}$ of $0.5 \%$ TCA containing $0.67 \%$ TBA was added to $2 \mathrm{~mL}$ of the supernatant. The mixture was incubated at $95{ }^{\circ} \mathrm{C}$ for $30 \mathrm{~min}$ and then instantly cooled on ice and centrifuged at $4{ }^{\circ} \mathrm{C}$ for $10 \mathrm{~min}$ at $5000 \times \mathrm{g}$. The absorbance of the supernatant was recorded at 450, $532 \mathrm{~nm}$, and $600 \mathrm{~nm}$.

EL of rice leaves was determined using an electrical conductivity meter (DDS-309+, Chengdu, China) following Ning et al. [79]. Relative EL was expressed as the ratio of initial conductivity to the conductivity after the samples were boiled for $15 \mathrm{~min}$ to achieve $100 \%$ electrolyte leakage.

\subsection{Trypan-Blue Staining}

Dead cells were visually detected using a Trypan-blue staining method as described by Liang et al. [80] with some modifications. Leaves were stained with lactophenol-Trypan blue solution for 20 min under vacuum conditions. The stained leaves were then decolorized in boiling ethanol $(90 \%, v / v)$ for $2 \mathrm{~h}$. Samples were equilibrated with $70 \%$ glycerol for scanning.

\subsection{Characteristics of Epidermis Cell and Stomata}

The upper and lower epidermis layers of rice leaves after $48 \mathrm{~h}$ of greening were observed using light microscopy by transparent nail polish imprint method [81]. The epidermis cells' characteristics and stomatal characteristics, including stomatal length, width, size, and density, were observed via Olympus fluorescence microscopy (DP71) $(40 \times 10)$ and measured and counted by an image analysis system (Image-Pro Plus 6.3). Five microscope fields were randomly selected in each slide. Each treatment group was repeated 50 times to measure all the characteristic parameters under the microscope.

\subsection{Statistical Analysis}

All experiments were repeated at least three times, and mean values are presented with standard deviation (SD). The data analysis was performed using IBM SPSS Statistics. Duncan's multiplication range test was used for comparison among different treatments. The difference was considered to be statistically significant when $p<0.05$.

\section{Conclusions}

In summary, our results showed that chilling stress induced ROS accumulation, leading to lipid peroxidation and cell death during greening. In particular, our data highlighted the detailed regulation of photosynthetic pigments under chilling stress during greening, suggesting that the inhibition of chlorophyll biosynthesis may be attributable to the blocked synthesis of ALA and the inhibition of conversion from Pchlide into chlorophylls. In this case, we have proposed that application of ALA or overexpression of $H E M A, D V R$, and CHLG may be good for increasing chlorophyll biosynthesis and improving cold resistance of rice seedlings during greening.

Supplementary Materials: Supplementary materials can be found at http://www.mdpi.com/1422-0067/21/4/1390/s1. Figure S1: Relative content of PSI proteins in control and chill-stressed rice seedlings. Figure S2: Relative content of PSI proteins in control and chill-stressed rice seedlings. Table S1: The primers used for quantitative real-time PCR.

Author Contributions: M.Y. and S.Y. designed the experiments; Y.Z., Q.H., C.D., Y.H., J.L., and T.C. performed the experiments. S.F., L.Z., Z.Z., and Y.C. analyzed the data and results. All authors have read and agreed to the published version of the manuscript.

Funding: This work was supported by Sichuan Agricultural University.

Conflicts of Interest: The authors declare no conflict of interest. 


\section{References}

1. Dalal, V.K.; Tripathy, B.C. Modulation of chlorophyll biosynthesis by water stress in rice seedlings during chloroplast biogenesis. Plant Cell Environ. 2012, 35, 1685-1703. [CrossRef] [PubMed]

2. Zhang, D.; Li, Y.H.; Zhang, X.Y.; Zha, P.; Lin, R.C. The SWI2/SNF2 chromatin-remodeling ATPase BRAHMA regulates chlorophyll biosynthesis in Arabidopsis. Mol. Plant 2017, 10, 155-167. [CrossRef]

3. Le, L.P.; Böddi, B.; Kovacevic, D.; Juneau, P.; Dewez, D.; Popovic, R. Spectroscopic analysis of desiccation-induced alterations of the chlorophyllide transformation pathway in etiolated Barley leaves. Plant Physiol. 2001, 127, 202-211. [CrossRef]

4. $\quad$ Tang, W.J.; Wang, W.Q.; Chen, D.Q.; Ji, Q.; Jing, Y.J.; Wang, H.Y.; Lin, R.C. Transposase-derived proteins FHY3/FAR1 interact with phytochrome-interacting factor1 to regulate chlorophyll biosynthesis by modulating HEMB1 during deetiolation in Arabidopsis. Plant Cell 2012, 24, 1984-2000. [CrossRef] [PubMed]

5. Eckhardt, U.; Grimm, B.; Hörtensteiner, S. Recent advances in chlorophyll biosynthesis and breakdown in higher plants. Plant Mol. Biol. 2004, 56, 1-14. [CrossRef] [PubMed]

6. Masuda, $\mathrm{T}$. Recent overview of the $\mathrm{Mg}$ branch of the tetrapyrrole biosynthesis leading to chlorophylls. Photosynth. Res. 2008, 96, 121-143. [CrossRef]

7. Nagata, N.; Tanaka, R.; Tanaka, A. The major route for chlorophyll synthesis includes [3,8-divinyl]chlorophyllide a reduction in Arabidopsis thaliana. Plant Cell Physiol. 2007, 48, 1803-1808. [CrossRef]

8. Moulin, M.; Smith, A.G. Regulation of tetrapyrrole biosynthesis in higher plants. Biochem. Soc. Trans. 2005, 33, 737-742. [CrossRef]

9. Yuan, M.; Zhao, Y.Q.; Zhang, Z.W.; Chen, Y.E.; Ding, C.B.; Yuan, S. Light regulates transcription of chlorophyll biosynthetic genes during chloroplast biogenesis. Crit. Rev. Plant Sci. 2017, 36, 35-54. [CrossRef]

10. Tanaka, R.; Tanaka, A. Tetrapyrrole biosynthesis in higher plants. Annu. Rev. Plant Biol. 2007, 58, 321-346. [CrossRef]

11. Tanaka, A.; Tanaka, R. Chlorophyll metabolism. Curr. Opin. Plant Biol. 2006, 9, 248-255. [CrossRef] [PubMed]

12. Vavilin, D.V.; Vermaas, W.F. Regulation of the tetrapyrrole biosynthetic pathway leading to heme and chlorophyll in plants and cyanobacteria. Physiol. Plant. 2010, 115, 9-24. [CrossRef] [PubMed]

13. Yuan, M.; Zhang, D.W.; Zhang, Z.W.; Chen, Y.E.; Yuan, S.; Guo, Y.R.; Lin, H.H. Assembly of NADPH: Protochlorophyllide oxidoreductase complex is needed for effective greening of barley seedlings. J. Plant Physiol. 2012, 169, 1311-1316. [CrossRef] [PubMed]

14. Sakuraba, Y.; Rahman, M.L.; Cho, S.H.; Kim, Y.S.; Koh, H.J.; Yoo, S.C.; Paek, N.C. The rice faded green leaf locus encodes protochlorophyllide oxidoreductase $\mathrm{B}$ and is essential for chlorophyll synthesis under high light conditions. Plant J. 2013, 74, 122-133. [CrossRef] [PubMed]

15. Masuda, T.; Takamiya, K. Novel insights into the enzymology, regulation and physiological functions of light-dependent protochlorophyllide oxidoreductase in angiosperms. Photosynth. Res. 2004, 81, 1-29. [CrossRef] [PubMed]

16. Rüdiger, W. Biosynthesis of chlorophyll $\mathrm{b}$ and the chlorophyll cycle. Photosynth. Res. 2002, 74, 187-193. [CrossRef]

17. Chen, G.; Bi, Y.R.; Li, N. EGY1 encodes a membrane-associated and ATP-independent metalloprotease that is required for chloroplast development. Plant J. 2005, 41, 364-375. [CrossRef]

18. Pogson, B.J.; Albrecht, V. Genetic dissection of chloroplast biogenesis and development: An overview. Plant Physiol. 2011, 155, 1545-1551. [CrossRef]

19. Leister, D. Chloroplast research in the genomic age. Trends Genet. 2003, 19, 47-56. [CrossRef]

20. Weston, E.; Thorogood, K.; Vinti, G.; López-Juez, E. Light quantity controls leaf-cell and chloroplast development in Arabidopsis thaliana wild type and blue-light-perception mutants. Planta 2000, 211, 807-815. [CrossRef]

21. Taşgın, E.; Atici, O.; Nalbantoğlu, B.; Popova, L.P. Effects of salicylic acid and cold treatments on protein levels and on the activities of antioxidant enzymes in the apoplast of winter wheat leaves. Phytochemistry 2006, 67, 710-715. [CrossRef] [PubMed]

22. Hu, Z.R.; Fan, J.B.; Xie, Y.; Amombo, E.; Liu, A.; Gitau, M.M.; Khaldun, A.B.M.; Chen, L.; Fu, J.M. Comparative photosynthetic and metabolic analyses reveal mechanism of improved cold stress tolerance in bermudagrass by exogenous melatonin. Plant Physiol. Biochem. 2016, 100, 94-104. [CrossRef] [PubMed] 
23. Bilska, A.; Pawe, S. Closure of plasmodesmata in maize (Zea mays) at low temperature: A new mechanism for inhibition of photosynthesis. Anna. Bot. 2010, 106, 675-686. [CrossRef] [PubMed]

24. Chaves, M.M.; Flexas, J.; Pinheiro, C. Photosynthesis under drought and salt stress: Regulation mechanisms from whole plant to cell. Ann. Bot. 2009, 103, 551-560. [CrossRef] [PubMed]

25. Lawlor, D.W.; Tezara, W. Causes of decreased photosynthetic rate and metabolic capacity in water-deficient leaf cells: A critical evaluation of mechanisms and integration of processes. Ann. Bot. 2009, 103, 561-579. [CrossRef]

26. Xie, G.; Kato, H.; Sasaki, K.; Imai, R. A cold-induced thioredoxin h of rice, OsTrx23, negatively regulates kinase activities of OsMPK3 and OsMPK6 in vitro. FEBS Lett. 2009, 583, 2734-2738. [CrossRef]

27. Nakashima, K.; Tran, L.S.; Nguyen, D.V.; Fujita, M.; Maruyama, K.; Todaka, D. Functional analysis of a NAC-type transcription factor OsNAC6 involved in abiotic and biotic stress responsive gene expression in rice. Plant J. 2007, 51, 617-630. [CrossRef]

28. Allen, D.J.; Ort, D.R. Impacts of chilling temperatures on photosynthesis in warm-climate plants. Trends Plant Sci. 2001, 6, 36-42. [CrossRef]

29. Fang, C.X.; Zhang, P.L.; Jian, X.; Chen, W.S.; Lin, H.M.; Li, Y.Z.; Lin, W.X. Overexpression of Lsi1 in cold-sensitive rice mediates transcriptional regulatory networks and enhances resistance to chilling stress. Plant Sci. 2017, 262, 115-126. [CrossRef]

30. Abdelkader, A.F.; Aronsson, H.; Sundqvist, C. High salt stress in wheat leaves causes retardation of chlorophyll accumulation due to a limited rate of protochlorophyllide formation. Physiol. Plant. 2010, 130, 157-166. [CrossRef]

31. Sharma, P.; Sharma, N.; Deswal, R. The molecular biology of the low temperature response in plants. Bioessays 2005, 27, 1048-1059. [CrossRef] [PubMed]

32. Kanneganti, V.; Gupta, A.K. Overexpression of OsiSAP8, a member of stress associated protein (SAP) gene family of rice confers tolerance to salt, drought and cold stress in transgenic tobacco and rice. Plant Mol. Biol. 2008, 66, 445-462. [CrossRef] [PubMed]

33. Kim, S.J.; Lee, S.C.; Hong, S.K.; An, K.; An, G.; Kim, S.R. Ectopic expression of a cold responsive OsAsr1 cDNA gives enhanced cold tolerance in transgenic rice plants. Mol. Cell 2009, 27, 449-458. [CrossRef] [PubMed]

34. Han, Q.H.; Huang, B.; Ding, C.B.; Zhang, Z.W.; Chen, Y.E.; Hu, C.; Zhou, L.J.; Huang, Y.; Liao, J.Q.; Yuan, S.; et al. Effects of melatonin on anti-oxidative systems and photosystem II in cold-stressed rice Seedlings. Front. Plant Sci. 2017, 8, 785. [CrossRef] [PubMed]

35. Jensen, P.E.; Reid, J.D.; Hunter, C.N. Modification of cysteine residues in the ChlI and ChlH subunits of magnesium chelatase results in enzyme inactivation. Biochem. J. 2000, 352, 435-441. [CrossRef] [PubMed]

36. Alberti, M.; Burke, D.H.; Hearst, J.E. Structure and sequence of the photosynthesis gene cluster. In Anoxygenic Photosynthetic Bacteria; Springer: Dordrecht, The Netherlands, 2004.

37. Zhang, H.T.; Li, J.J.; Yoo, J.H.; Yoo, S.C.; Cho, S.H.; Koh, H.J.; Seo, H.S.; Paek, N.C. Rice Chlorina-1 and Chlorina-9 encode ChlD and ChlI subunits of Mg-chelatase, a key enzyme for chlorophyll synthesis and chloroplast development. Plant Mol. Biol. 2006, 62, 325-337. [CrossRef]

38. Liu, X.C.; Chen, C.Y.; Wang, K.C.; Luo, M.; Tai, R.; Yuan, L.Y. Phytochrome interacting factor3 associates with the histone deacetylase HDA15 in repression of chlorophyll biosynthesis and photosynthesis in etiolated Arabidopsis seedlings. Plant Cell 2013, 25, 1258-1273. [CrossRef]

39. Czarnecki, O.; Grimm, B. Post-translational control of tetrapyrrole biosynthesis in plants, algae, and cyanobacteria. J. Exp. Bot. 2012, 63, 1675-1687. [CrossRef]

40. Richter, A.S.; Banse, C.; Grimm, B. The GluTR-binding protein is the heme-binding factor for feedback control of glutamyl-tRNA reductase. eLife 2019, 8, e46300. [CrossRef]

41. Schmied, J.; Hou, Z.W.; Hedtke, B.; Grimm, B. Controlled partitioning of glutamyl-tRNA reductase in stromaand membrane-associated fractions affects the synthesis of 5-aminolevulinic acid. Plant Cell Physiol. 2018, 59, 2204-2231. [CrossRef]

42. Apitz, J.; Nishimura, K.; Schmied, J.; Wolf, A.; Hedtke, B.; van Wijk, K.J.; Grimm, B. Posttranslational control of ALA synthesis includes GluTR degradation by Clp protease and stabilization by GluTR-binding protein. Plant Physiol. 2016, 170, 2040-2051. [CrossRef] [PubMed]

43. Kumar, T.A.; Charan, T.B. Temperature-stress-induced impairment of chlorophyll biosynthetic reactions in cucumber and wheat. Plant Physiol. 1998, 117, 851-858. [CrossRef] [PubMed] 
44. Beale, S.I. Enzymes of chlorophyll biosynthesis. Photosynth. Res. 1999, 60, 43-73. [CrossRef]

45. Oosawa, N.; Masuda, T.; Awai, K.; Fusada, N.; Shimada, H.; Ohta, H. Identification and light-induced expression of a novel gene of NADPH-protochlorophyllide oxidoreductase isoform in Arabidopsis thaliana. FEBS Lett. 2000, 474, 133-136. [CrossRef]

46. Frick, G.; Su, Q.; Apel, K.; Armstrong, G.A. An Arabidopsis porB porC double mutant lacking light-dependent NADPH: Protochlorophyllide oxidoreductases B and C is highly chlorophyll-deficient and developmentally arrested. Plant J. 2010, 35, 141-153. [CrossRef]

47. Li, H.; Xu, H.L.; Zhang, P.J.; Gao, M.Q.; Wang, D.; Zhao, H.J. High temperature effects on D1 protein turnover in three wheat varieties with different heat susceptibility. Plant Growth Regul. 2016, 81, 1-9. [CrossRef]

48. Wang, P.; Sun, X.; Chang, C.; Feng, F.J.; Liang, D.; Cheng, L.L.; Ma, F.W. Delay in leaf senescence of Malus hupehensis by long-term melatonin application is associated with its regulation of metabolic status and protein degradation. J. Pineal Res. 2013, 55, 424-434.

49. Chen, Y.E.; Cui, J.M.; Su, Y.Q.; Yuan, S.; Yuan, M.; Zhang, H.Y. Influence of stripe rust infection on the photosynthetic characteristics and antioxidant system of susceptible and resistant wheat cultivars at the adult plant stage. Front. Plant Sci. 2015, 6, 779-790. [CrossRef]

50. Pamplona, R. Advanced lipoxidation end-products. Chem. Biol. Interact. 2011, 192, 14-20. [CrossRef]

51. Shi, H.T.; Jiang, C.; Ye, T.T.; Tan, D.X.; Reiter, R.J.; Zhang, H.; Liu, R.Y.; Chan, Z.L. Comparative physiological, metabolomic, and transcriptomic analyses reveal mechanisms of improved abiotic stress resistance in Bermuda grass [Cynodon dactylon (L). Pers.] by exogenous melatonin. J. Exp. Bot. 2015, 66, 681-694. [CrossRef]

52. Los, D.A.; Murata, N. Membrane fluidity and its roles in the perception of environmental signals. BBA Biomembr. 2004, 1666, 142-157. [CrossRef] [PubMed]

53. Yun, K.Y.; Park, M.R.; Mohanty, B.; Herath, V.; Xu, F.; Mauleon, R.; Wijaya, E.; Bajic, V.B.; Bruskiewich, R.; de Los Reyes, B.G. Transcriptional regulatory network triggered by oxidative signals configures the early response mechanisms of japonica rice to chilling stress. BMC Plant Biol. 2010, 10, 16. [CrossRef]

54. Tian, Y.; Zhang, H.W.; Pan, X.W.; Chen, X.L.; Zhang, Z.J.; Lu, X.Y.; Huang, R.F. Overexpression of ethylene response factor TERF2 confers cold tolerance in rice seedlings. Transgenic Res. 2011, 20, 857-866. [CrossRef] [PubMed]

55. Sangwan, V.; Örvar, B.L.; Beyerly, J.; Hirt, H.; Dhindsa, R.S. Opposite changes in membrane fluidity mimic cold and heat stress activation of distinct plant MAP kinase pathways. Plant J. 2002, 31, 629-638. [CrossRef] [PubMed]

56. Chinnusamy, V.; Zhu, J.; Zhu, J.K. Gene regulation during cold acclimation in plants. Physiol. Plant. 2006, 126, 52-61. [CrossRef]

57. Zhang, Q.; Jiang, N.; Wang, G.L.; Hong, Y.H.; Wang, Z.L. Advances in understanding cold sensing and the cold-responsive network in rice. Adv. Crop Sci. Tech. 2013, 1, 104.

58. Liu, T.; Xu, J.J.; Zhang, J.; Li, J.M.; Hu, X.H. Exogenous 5 aminolevulinic acid pretreatment ameliorates oxidative stress triggered by low temperature stress of Solanum lycopersicum. Acta Physiol. Plant. 2018, 40, 210. [CrossRef]

59. Balestrasse, K.B.; Tomaro, M.L.; Batlle, A.; Noriega, G.O. The role of 5-aminolevulinic acid in the response to cold stress in soybean plants. Phytochemistry 2010, 71, 2038-2045. [CrossRef]

60. Guo, X.T.; Li, Y.S.; Yu, X.C. Promotive effects of 5-aminolevulinic acid on photosynthesis and chlorophyll fluorescence of tomato seedlings under suboptimal low temperature and suboptimal photon flux density stress. Hortic. Sci. 2012, 39, 97-99.

61. Liu, D.; Kong, D.D.; Fu, X.K.; Ali, B.; Xu, L.; Zhou, W.J. Influence of exogenous 5-aminolevulinic acid on chlorophyll synthesis and related gene expression in oilseed rape de-etiolated cotyledons under water-deficit stress. Photosynthetica 2016, 54, 468-474. [CrossRef]

62. Shalygo, N.V.; Czarnecki, O.; Peter, E.; Grimm, B. Expression of chlorophyll synthase is also involved in feedback-control of chlorophyll biosynthesis. Plant Mol. Biol. 2009, 71, 425-436. [CrossRef] [PubMed]

63. Lichtenthaler, H.K.; Wellburn, A.R. Determination of total carotenoids and chlorophylls a and b of leaf in different solvents. Biochem. Soc. Trans. 1983, 11, 591-592. [CrossRef]

64. Bradford, M.M. A rapid and sensitive method for the quantitation of microgram quantities of protein utilizing the principle of protein-dye binding. Anal. Biochem. 1976, 72, 248-254. [CrossRef] 
65. Dei, M. Benzyladenine-induced stimulation of 5-aminolevulinic acid accumulation under various light intensities in levulinic acid-treated cotyledons of etiolated cucumber. Physiol. Plant. 1985, 64, 153-160. [CrossRef]

66. Bogorad, L.; Colowick, S.P.; Kaplan, N.O. Methods in Enzymology; Academic Press: New York, NY, USA, 1962.

67. Rebeiz, C.A.; Mattheis, J.R.; Smith, B.B.; Mattheis, J.R.; Rebeiz, C.C.; Dayton, D.F. Chloroplast biogenesis: Biosynthesis and accumulation of Mg-protochlorophyrin IX monoester and other metalloporphyrins by isolated etioplasts and developing chloroplasts. Arch. Biochem. Biophys. 1975, 167, 351-365. [CrossRef]

68. Wilks, A. Analysis of Heme and Hemoproteins; Humana Press: Totowa, NJ, USA, 2002.

69. Yaronskaya, E.; Ziemann, V.; Walter, G.; Averina, N.; Borner, T.; Grimm, B. Metabolic control of the tetrapyrrole biosynthetic pathway for porphyrin distribution in the barley mutant albostrians. Plant J. 2010, 35, 512-522. [CrossRef]

70. Chen, J.B.; Li, X.Y.; Cheng, C.; Wang, Y.H.; Mao, Q.; Zhu, H.T.; Zeng, R.Z.; Fu, X.L.; Liu, Z.Q.; Zhang, G.Q. Characterization of epistatic interaction of QTLs LH8 and EH3 controlling heading date in rice. Sci. Rep. 2014, 4, 4263. [CrossRef]

71. Fristedt, R.; Granath, P.; Vener, A.V. A protein phosphorylation threshold for functional stacking of plant photosynthetic membranes. PLoS ONE 2010, 5, e10963. [CrossRef]

72. Aro, E.M.; Mccaffery, S.; Anderson, J.M. Photoinhibition and D1 protein degradation in peas acclimated to different growth irradiances. Plant Physiol. 1993, 103, 835-843. [CrossRef]

73. Chen, Y.E.; Yuan, S.; Du, J.B.; Xu, M.Y.; Zhang, Z.W.; Lin, H.H. Phosphorylation of photosynthetic antenna protein CP29 and photosystem II structure changes in monocotyledonous plants under environmental stresses. Biochemistry 2009, 48, 9757-9763. [CrossRef]

74. Sakamoto, W.; Uno, Y.; Zhang, Q.; Miura, E.; Kato, Y. Arrested differentiation of proplastids into chloroplasts in variegated leaves characterized by plastid ultrastructure and nucleoid morphology. Plant Cell Physiol. 2009, 50, 2069-2083. [CrossRef] [PubMed]

75. Zhou, S.B.; Liu, K.; Zhang, D.; Li, Q.F.; Zhu, G.P. Photosynthetic performance of Lycoris radiata var. radiata to shade treatments. Photosynthetica 2010, 48, 241-248. [CrossRef]

76. Yang, Y.N.; Qi, M.; Mei, C.S. Endogenous salicylic acid protects rice plants from oxidative damage caused by aging as well as biotic and abiotic stress. Plant J. 2010, 40, 909-919. [CrossRef] [PubMed]

77. Velikova, V.; Yordanov, I.; Edreva, A. Oxidative stress and some antioxidant systems in acid rain-treated bean plants: Protective role of exogenous polyamines. Plant Sci. 2000, 151, 59-66. [CrossRef]

78. Nahar, K.; Hasanuzzaman, M.; Alam, M.M.; Fujita, M. Roles of exogenous glutathione in antioxidant defense system and methylglyoxal detoxification during salt stress in mung bean. Biol. Plant. 2015, 59, 745-756. [CrossRef]

79. Ning, J.F.; Ai, S.Y.; Yang, S.H.; Cui, L.H.; Cheng, Y.; Sun, L.L. Physiological and antioxidant responses of Basella alba to $\mathrm{NaCl}$ or $\mathrm{Na}_{2} \mathrm{SO}_{4}$ stress. Acta Physiol. Plant. 2015, 37, 126. [CrossRef]

80. Liang, C.Z.; Zheng, G.Y.; Li, W.Z.; Wang, Y.Q.; Hu, B.; Wang, H.R. Melatonin delays leaf senescence and enhances salt stress tolerance in rice. J. Pineal Res. 2015, 59, 91-101. [CrossRef]

81. Berger, D.; Altmann, T. A subtilisin-like serine protease involved in the regulation of stomatal density and distribution in Arabidopsis thaliana. Genes Dev. 2000, 14, 1119-1131.

(C) 2020 by the authors. Licensee MDPI, Basel, Switzerland. This article is an open access article distributed under the terms and conditions of the Creative Commons Attribution (CC BY) license (http://creativecommons.org/licenses/by/4.0/). 